\title{
Dread of Depreciation: Measuring Real Exchange Rate Interventions
}

\author{
Jayasri Dutta and Hyginus Leon
}





\title{
IMF Working Paper
}

IMF Institute

\section{Dread of Depreciation: Measuring Real Exchange Rate Interventions}

Prepared by Jayasri Dutta and Hyginus Leon ${ }^{1}$

Authorized for distribution by Eric V. Clifton

April 2002

\begin{abstract}
The views expressed in this Working Paper are those of the author(s) and do not necessarily represent those of the IMF or IMF policy. Working Papers describe research in progress by the author(s) and are published to elicit comments and to further debate.
\end{abstract}

We specify an empirical framework to detect the effects of official intervention on real exchange rate dynamics. Using data for 27 advanced and emerging market economies, we find evidence that interventions are a near-universal practice; almost all countries intervene when real exchange rates depreciate; interventions reduce the degree of persistence in real exchange rates; and the defense of an overvalued currency tends to be contractionary.

JEL Classification Numbers: C22, F31

Keywords: Real exchange rates; interventions; parity conditions

Author’s E-Mail Address: j.dutta@bham.ac.uk; hleon@imf.org

\footnotetext{
${ }^{1}$ University of Birmingham, England and IMF Institute, respectively. We are grateful for helpful comments from Temisan Agbeyegbe, Marco Barassi, Paul Cashin, Eric Clifton, Andrew Feltenstein, John Fender, Martin Kaufman, Christopher Rowe, Sunil Sharma, and Robert Taylor, none of whom are responsible for remaining errors.
} 


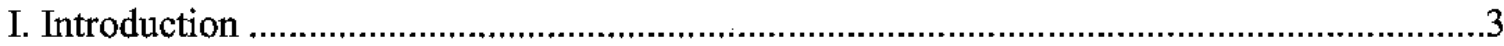

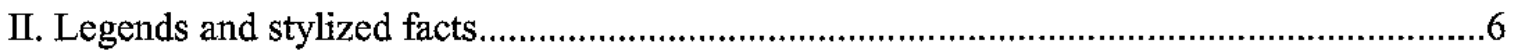

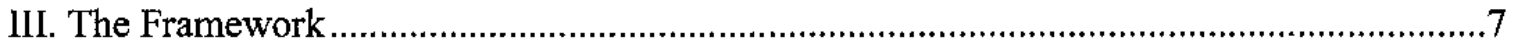

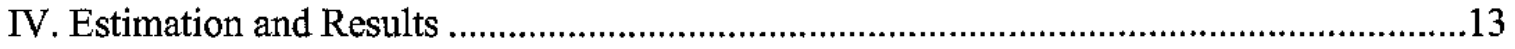

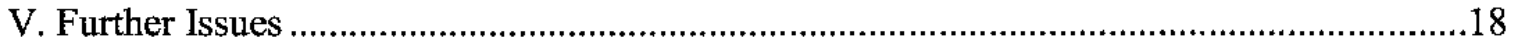

Tables

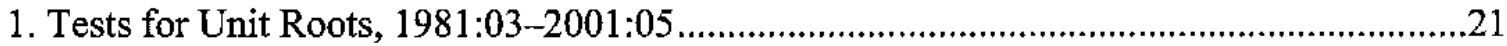

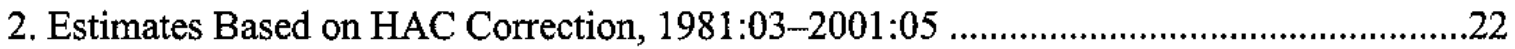

3. Estimates Based on Minimum AIC, 1981:03-2001:05 …..............................................24

Figure

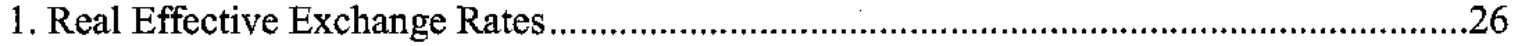

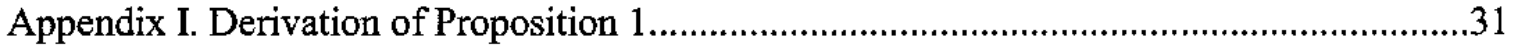

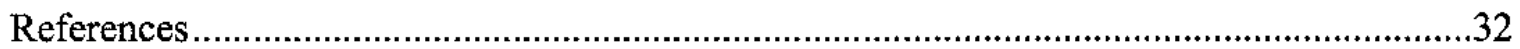




\section{INTRODUCTION}

The hypothesis that many countries, especially those with emerging markets, systematically intervene in the exchange markets for their own currencies has been argued by Calvo and Reinhart $(2000,2001)$, who refer to this as "fear of floating." While many countries have moved from fixed to floating exchange rates over the last twenty years, their nominal exchange rates vary relatively little: most variations are less than 1 percent and virtually all variations are less than 2.5 percent. This is quite striking relative to variations in the dollar relative to the yen or the deutsche mark. The evidence is strengthened by the fact that the usual outcomes of intervention-nominal interest rate changes or changes in international reserves - are highly volatile, suggesting that repeated interventions are used to maintain the price of domestic currencies. It turns out, then, that the float of such currencies is in name only, and given this fear of floating, the demise of fixed exchange rates is a myth.

In this paper, we develop empirical methods designed to detect the effects of intervention on real exchange rate dynamics, and apply them to the real effective exchange rates of several countries, including several classified as emerging market economies. We find strong evidence of intervention across the board: "fear of floating" is near universal; perhaps surprisingly, this is not limited to emerging markets. There is a clear pattern in the types of intervention that we detect: emerging market economies typically intervene when their currencies depreciate below a threshold level. Their fear of floating is thus better diagnosed as a "dread of depreciation."

We detect interventions by studying the dynamics of real exchange rates, rather than their volatility. This is motivated by the fact that there is not much to pin down the volatility of exchange rates, nominal or real. The behavior of exchange rates for industrial countries is a minefield of puzzles relative to the predictions of economic theory or financial economics. Excess volatility of exchange rates is surely one of the leading puzzles: the fact that this volatility exceeds that of fundamentals, and at the same time, that it simultaneously does not affect real fundamentals, is termed the "exchange rate disconnect puzzle" by Obstfeld and Rogoff (2000). With this in mind, it is particularly difficult to interpret the evidence that nominal exchange rates are "insufficiently volatile" in emerging markets: in the absence of a systematic explanation, it is unlikely that we can predict just how volatile the baht, the won, or the rupee should be.

As it turns out, our analysis is related to another enduring puzzle, relating to purchasing power parity. Real exchange rates measure deviations from PPP; they are volatile, of course, but highly persistent in addition, often referred to as the "PPP puzzle". It is usually difficult to reject the hypothesis that real exchange rates are non-stationary because they appear to have a unit root. At the very least, the half-life of PPP deviations are around 3-4 years; our analysis replicates this finding from the application of standard unit root tests. Our hypothesis starts from the fact that persistent and large deviations from PPP can trigger government intervention; governments care about these deviations because real exchange rates are likely to affect net exports, as well the cost of servicing debt denominated in foreign currency. This intervention could be directly in currency markets, using foreign currency reserves for example; it could also reflect monetary policy interventions that affect domestic price levels. 
Effective policy interventions that have a substantial effect on either nominal exchange rates, or price levels, with slower response in the other are likely to show up in real exchange rate dynamics. $^{2}$

We start from the qualitative hypothesis that governments try to limit the range of variation of their exchange rates, and are likely to intervene when their real exchange rate is particularly high or low. ${ }^{3}$ Our formal model consists of four elements. First, the behavior of the real exchange rate with and without intervention. Second, the policy rule followed by a government that attempts to keep real exchange rate within a band. Third, uncovered interest parity, arising from non-arbitrage in bond markets. Finally, market participants have rational expectations and can predict systematic policy interventions. Together, this allows us to derive the equilibrium dynamics of interest rates and exchange rates. We show that systematic policy intervention has testable implications about the dynamics of real exchange rates.

We then estimate the model for 27 countries, using monthly data on real effective exchange rates. Our sample includes all G7 countries; and a mix of further industrial countries as well emerging market economies. Importantly, we imagine that governments target the real exchange rate, and our methods can be used irrespective of the exchange rate regime prevailing. Countries with fixed, pegged, or managed float of currencies have access to the direct instrument of changing the nominal exchange rate as well as indirect instruments including discount window rates, changes in foreign currency reserves, and measures of restoring market confidence. We evaluate the impact of successful intervention, but not the use of instruments. This allows us to compare the extent of intervention across countries. The availability of instruments are likely to be an important factor in explaining the frequency of interventions as well as their likely cost: evaluating their role is a clear priority in further analysis.

We start from a structural model, and this allows us to test hypotheses about deep parameters relating to the fundamentals of the policy rule and currency markets. Two of these are of particular interest, and we concentrate on these. The first is the basic hypothesis of this study: does country X suffer from fear of floating? This translates to a null hypothesis of "no effective intervention" -25 of our 27 countries fail the test. ${ }^{4}$ Canada and Malaysia are the

\footnotetext{
${ }^{2}$ Systematic interventions can be deduced by traders in bond and currency markets, and affect expectations and interest rate differentials as well as exchange rates.

${ }^{3}$ Calvo and others (1995) state that the real exchange rate is probably the most popular real target in developing countries, a common rationale being to avoid loss of competitiveness.

${ }^{4}$ In a recent study, Wickham (2002) finds that daily nominal exchange returns for some developed and developing countries may be classified as white noise but not independent and identically distributed (iid) processes. While the analysis does not detect intervention in the data, he cautions that the results do not imply the absence of foreign market intervention or no use of monetary policy instruments to influence the exchange rate.
} 
only countries for which we find no significant evidence of effective intervention. So, "fear of floating" is a common disease, not special to emerging markets (EM). We look for evidence of potentially asymmetric interventions: countries may choose to resist depreciations more vigorously than appreciations. In this, we find that all but two countries in our sample defended depreciations: their "fear of floating" can be qualified as a "dread of depreciation." As regards defending an overvalued currency, all advanced economies and about one half of the EMs do.

We look for "range reversion" in real exchange rates as a test for intervention. Application of the test to industrial countries, as well as emerging markets, was designed to provide a standard of comparison, in much the same spirit as Calvo and Reinhart (2000). As it turns out, the test is "too" successful, as we find evidence of range-reversion in the US dollar and the Yen, as well as most European currencies. This raises a question: is it possible that the observed "range reversion" in the US dollar, for example, is due to something other than intervention? An alternative hypothesis relates range reversion to fixed costs of trading; Obstfeld \& Rogoff (2000) suggest that the cost of transporting goods can explain most of the leading puzzles in international finance. Michael, Nobay \& Peel (1997) estimate a model of nonlinear range reversion arising from fixed costs of transactions in currency markets. Importantly, their prediction is that of "two-sided" range reversion as we find for several industrial countries. All three models predict range reversion in real exchange rates: a serious evaluation of evidence for one or another would require that we track the use of policy instruments, and also that we test for differential range reversion in nominal exchange rates and in inflation.

Our estimates generate predictions about purchasing power parity. Real exchange rates are known to be highly persistent, suggesting that deviations from purchasing power parity take a very long time to die out, a slow parity reversion rate of between 13 to 20 percent (Meese and Rogoff (1988), Froot and Rogoff (1995), Rogoff (1996), Cashin and McDermott (2001)). It is difficult to reject the hypothesis of a unit root in real exchange rates, implying lack of convergence. Recent studies find less evidence of unit root behavior, arguing that the power of standard tests for unit roots are low when the sample size is small or when the true model is nonlinearly mean reverting (Yilmaz (2001), Bergman and Hansson (2000), De Grauwe and Vansteenkiste (2001), Kilian and Taylor (2001)). Sarno and Taylor (2001) list three reasons why we should care if the real exchange rate is a unit root. First, the degree of persistence can be used to infer the principal impulses driving real exchange rate movements, high persistence indicating principally supply side shocks. Second, nonstationarity questions a large part of open economy macroeconomic theory that assumes PPP. Third, policy based on estimates of PPP exchange rates may be flawed if the real exchange rate contains a unit root. We argue that interventions that dampen large changes in real exchange rates, positive or negative, can induce stationarity in the presence of a unit root, and so ensure faster convergence to PPP, by range reversion if not mean reversion. With this in mind, we test whether the real exchange rate process is stationary after interventions are accounted for, and find strong evidence in favor of this hypothesis for about one half of the countries in our sample. 
We then turn to the likely effects of exchange rate interventions. Defended depreciations are likely to increase interest rates and have a contractionary effect on output. The net effect of interventions on real interest rates depends on the structural parameters; the direction can be tested using the reduced form. We do not find evidence suggesting that defended depreciations incur a cost of lower output, because the real interest effect of intervention is negative. Our results also show that defended depreciations are expansionary for most countries in our sample.

The rest of this paper is organized as follows. Section II summarizes some legends and stylized facts on exchange rates. Section III discusses the framework used to derive our estimating equation, while Section IV presents the results. A brief summary and issues for further research follow in Section $V$.

\section{LEGENDS AND STYLIZED FACTS}

Exchange rates affect both the relative price of goods and the return differential on assets. The first effect dictates purchasing power parity (PPP); the second dictates uncovered interest parity (UIP). These two relationships are central to the study of international economics. However, empirical studies of exchange rates - real or nominal - are plagued by a very large number of puzzles, that are difficult to explain in terms of the standard tools of international economics (see, in particular, Obstfeld and Rogoff (2000)). Not all these puzzles, or stylized facts, are pertinent to our analysis. We list some of these facts that can help put our analysis in perspective (see also Edwards and Savastano, 1999).

1. At least for advanced economies, deviations from purchasing power parity are highly persistent, and a substantial body of evidence suggests that the real exchange rate, measuring deviations from PPP, are indistinguishable from non-stationary time series (they behave like $I(1)$ processes) (see, for example, Rogoff (1996)). However, very long run data, of 150 years or more, suggest mean reversion (e.g., Lothian and Taylor (1997) ), at the cost of transcending dramatic changes in institutions of international trade and finance. ${ }^{5}$ If the true model is nonlinearly mean reverting, standard unit root tests are likely to have low power to reject the null of a unit root. Michael, Nobay and Peel (1997), and Bergman and Hansson (2000) find evidence of non-linear stationarity; ${ }^{6}$ we do also, but with a very different interpretation.

2. Nominal exchange rates are excessively volatile relative to domestic and foreign prices; put another way, real exchange rates are volatile. At the same time, real

\footnotetext{
${ }^{5}$ Evidence in favor of PPP has also been found using non-stationary panel techniques, which increase the span of the data while minimizing the effects of potential structural breaks (Frankel and Rose (1996), O'Connell (1997), and Papell (1998)). However, these methods are also subject to the "near-unit-root bias," which favors finding PPP. For a confidenceinterval-based method to overcome the power issue, see Cashin and McDermott (2001).

${ }^{6}$ Cheung and Lai (1993) also find stationarity but using fractional integration models.
} 
exchange rate volatility appears to be output neutral, a phenomenon termed the "exchange rate disconnect puzzle" by Obstfeld and Rogoff (1996). This volatility varies across currencies: in our data for example, the standard deviation of real effective exchange rates varies by a factor of 14 ( 4 for France to 56 for Indonesia); percentage changes in real effective exchange rates vary by a factor of $8(0.9$ percent for France and Germany to 7.7 percent for Argentina). In our framework, interventions attempt to control volatility but cannot reduce them to zero.

3. A small group of studies (Kamin and Rogers (2000), Levy-Yeyati and Sturzenegger (2001)) find that exchange rate misalignments have output effects. Typically, deliberate undervaluations are counterproductive, while measured exchange rate flexibility is positively correlated with growth in EMs. ${ }^{7}$ Our analysis suggests that the method of correcting for misalignments may be an important determinant of real effects.

4. Recent experience- - the Mexican and Asian crises--suggest that currency depreciations can trigger serious contractions. The important issue, once again, is the likely cost of "defended depreciations"; for all of these countries, we find substantive evidence of interventions when the real exchange rate falls.

5. Calvo and Reinhart $(2000,2001)$ provide a wide-ranging body of evidence to support the hypothesis that EMs suffer from a fear of floating. Among these, that the effective range of exchange rate changes are much smaller in EMs; and that the typical effects of intervention -changes in nominal interest rates and international reserves--are significantly more volatile than in industrial economies. Our analysis is motivated directly by their analysis. In effect, we explore the implications of intervention on the dynamics of real exchange rates.

6. The last relevant fact has to do with uncovered interest parity (UIP). Empirically, UIP fares better than PPP (Taylor (1995)), though the results are extremely sensitive to the exact econometric specification. Typically, level regressions favor UIP but difference regressions reject it. Importantly, McCallum (1994) shows that these two can be reconciled by an appropriate hypothesis about systematic policy intervention, as we specify.

\section{The FramewORK}

We define a real exchange rate intervention as any set of policy measures aimed at effecting the REER, including periodic devaluations, central bank foreign exchange market transactions, and interest rate changes. As usual, we write capitals for levels, and lower case

${ }^{7}$ Calvo and others (1995) argue that real exchange rate targeting leads to some combination of higher inflation and higher domestic real exchange rates, while Goldfajn and Valdés (1996) find that appreciations are more likely to be undone by changes in the nominal exchange exchange rates as opposed to changes in inflation differentials. 
for logarithms, and $\Delta$ for differences. So, $E R_{t}$ is the real exchange rate at time $t$, measured as dollars per unit of home currency; $e_{t}=\log \left(E R_{t}\right)$. Similarly, $R_{t}$ is the domestic interest rate, and $R_{t}^{*}$ the world interest rate, with $r_{t}, r_{t}^{*}$ as their logarithms. We write $z_{t}=r_{t}-r_{t}^{*}$ as the interest rate differential.

The model has three ingredients: a basic equation of exchange rate dynamics $(\mathbf{X})$; an explicit policy rule (P) that limits the variability of exchange rates; and the interest parity relation (I). We specify a direct policy rule, rather than a loss function. This policy rule can be rationalized as the optimal response of a government minimizing the mean squared error of the real exchange rate around a target value $\bar{e}$, subject to the cost of intervention $C(s)$. Fixed costs of intervention $(C(s)>0$ whenever $s>0$ ) would imply non-trivial tolerance bands $\left(e_{L}<\bar{e}<e_{H}\right.$ ); and asymmetries in interventions costs would correspond to asymmetric responses to depreciations and appreciations.

First, we assume that exchange rate dynamics evolve according to

$$
e_{t+1}=\rho e_{t}+\beta z_{t}+s_{t+1}+u_{t+1}
$$

where $0 \leq \rho \leq 1$, and $u_{t}$ is a stationary random variable with finite variance and $E_{t} u_{t+1}=0$. $s_{t}$ is a policy shock that affects the exchange rate in the short term, and is chosen by governments that may want to intervene. Define

$$
\bar{e}_{t}=\rho e_{t-1}+\beta z_{t-1}
$$

as the "fundamental" value of the exchange rate. From the definitions, this is its expected value in the absence of intervention, as $\left.E_{t-1} e_{t}\right|_{s_{t}=0}=\bar{e}_{t}$. This model closely follows that of McCallum (1994). We distinguish between the policy instrument $s_{t+1}$, that can include interest rates, and $z_{t}$, which measures the lagged effect of interest rates. A positive $\beta$ can explain persistence in monetary policy effects and a negative one indexes reversion to fundamentals. Importantly, $\beta=0$ is consistent with our analysis and implies the standard formulation used in tests for unit roots.

As regards the policy rule, we want to think of $s_{t}$ as an instrument used infrequently, as a "surprise" expansion or contraction, for the specific purpose of preventing extreme variations of $e_{t}$. Policies $s_{t}$ are chosen before $u_{t}$ is observed. Nevertheless, the government observes $e_{t-1}$ as well as $z_{t-1}$, and deduces $\bar{e}_{t}$. The exchange rate $e_{t}$ is likely to appreciate at $t$ if $\bar{e}_{t}$ is low, and depreciate when it is high. Suppose, specifically, $\left[e_{L}, e_{H}\right]$ is the zone of tolerance, so that

$$
s_{t}=0 \text { whenever } e_{L} \leq \bar{e}_{t} \leq e_{H}
$$


When $\vec{e}_{t}$ falls below $e_{L}$, policy-makers intervene to attempt an appreciation, as follows:

$$
s_{t}=\lambda_{L}\left(e_{L}-\bar{e}_{t}\right) \text { if } \bar{e}_{t}<e_{L}
$$

similarly, when $\bar{e}_{t}$ rises, policy-makers intervene to attempt a depreciation:

$$
s_{t}=\lambda_{H}\left(e_{H}-\bar{e}_{t}\right) \text { if } e_{H}<\bar{e}_{t}
$$

where $0 \leq \lambda_{i} \leq 1, i=L, H$. Conditions (PL), (P0), (PH) define the policy rule

$$
s_{t}=\lambda\left(\bar{e}_{t}\right)
$$

We allow the policy rule to be asymmetric; this, as well as the existence of a non-trivial tolerance zone $\left[e_{L}, e_{H}\right]$ with $e_{H}>e_{L}$ are testable hypotheses. Lack of intervention corresponds to $\lambda_{l}=\lambda_{H}=0$ while perpetual intervention implies $e_{H}=e_{L}$ and $\lambda_{i}>0$. Finally, $\lambda_{H}=\lambda_{L}=1$ corresponds to maximal stabilization. If in addition, $e_{H}=e_{L}=\bar{e}_{t}$, the government attempts maintaining a real peg.

To complete the specification, we turn to uncovered interest parity: no gains can be expected from borrowing abroad and lending at home or vice versa. This is

$$
E_{t} e_{t+1}=e_{t}+r_{t}^{*}-r_{t}=e_{t}-z_{t}
$$

We assume that interest parity holds at each time, and that this is exact. Market participants know the policy rule $(\mathbf{P})$, and expectations are rational:

$$
E_{t} e_{t+1}=\bar{e}_{t+1}+\lambda\left(\bar{e}_{t+1}\right)
$$

Interest parity implies

$$
\bar{e}_{t+1}+\lambda\left(\bar{e}_{t+1}\right)=e_{t}-z_{t}
$$

at each time $t$. We now show that (X), (P), and (I) fully determine the path of the interest rate differential $z_{t}$, and hence domestic interest rates $r_{t}$. This allows us to determine an explicit reduced form for the dynamics of the exchange rate in the presence of intervention. This is reported in Proposition 1, which sets out our estimating equations. Define the coefficients $\mu_{i}$ and $\theta_{i}$ as

$$
\mu_{L}=\frac{\lambda_{L} e_{L}}{1+\beta\left(1-\lambda_{L}\right)} ; \mu_{H}=\frac{\lambda_{H} e_{H}}{1+\beta\left(1-\lambda_{H}\right)} ; \text { and }
$$




$$
\theta_{L}=\frac{\left(1-\lambda_{L}\right)(\beta+\rho)}{1+\beta\left(1-\lambda_{L}\right)} ; \theta_{0}=\frac{\beta+\rho}{1+\beta} ; \theta_{H}=\frac{\left(1-\lambda_{H}\right)(\beta+\rho)}{1+\beta\left(1-\lambda_{H}\right)}
$$

Proposition 1: Suppose that exchange rates satisfy (X), policy interventions satisfy (P), and interest parity (I) holds at each time $t$. With rational expectations, the sequence of interest rate differentials, $z_{t}$, and exchange rates, $e_{t}$ are

$$
\begin{aligned}
& \left.\begin{array}{l}
z_{t}=-\mu_{L}+\left(1-\theta_{L}\right) e_{t} \\
e_{t+1}=\mu_{L}+\theta_{L} e_{t}+u_{t}
\end{array}\right\} \quad \text { whenever } e_{t}<e_{L} \frac{1+\beta}{\beta+\rho} \\
& \left.\begin{array}{l}
z_{t}=\left(1-\theta_{0}\right) e_{t} \\
e_{t+1}=\theta_{0} e_{t}+u_{t}
\end{array}\right\} \quad \text { whenever } e_{L} \frac{1+\beta}{\beta+\rho} \leq e_{t} \leq e_{H} \frac{1+\beta}{\beta+\rho} \\
& \left.\begin{array}{l}
z_{t}=-\mu_{H}+\left(1-\theta_{H}\right) e_{t} \\
e_{t+1}=\mu_{H}+\theta_{H} e_{t}+\mu_{t}
\end{array}\right\} \quad \text { whenever } e_{H} \frac{1+\beta}{\beta+\rho}<e_{t}
\end{aligned}
$$

(see Appendix for details).

\section{Properties}

In proposition 1, we derive our fundamental estimating equation in the form

$$
e_{t+1}= \begin{cases}\mu_{L}+\theta_{L} e_{t}+u_{t} & \text { if } \quad e_{t}<e_{L}^{*} \\ \theta_{0} e_{t}+u_{t} & \text { if } e_{L}^{*} \leq e_{t} \leq e_{H}^{*} \\ \mu_{H}+\theta_{H} e_{t}+u_{t} & \text { if } e_{H}^{*}<e_{t}\end{cases}
$$

This is a switching autoregression of order one in the real exchange rate $e_{t}$. In the nonintervention zone (zone of tolerance), the null hypothesis is that $e_{t}$ is a random walk; in the intervention zones, we would expect the true model to have a drift term. The parameters of this equation have important implications for economic and policy questions that motivate this work. We evaluate some of them.

\section{Parity conditions}

Exchange rates are expected to satisfy purchasing power parity (PPP) as well as Uncovered Interest Parity (UIP). We assume that UIP holds at every point. Exact PPP requires $e_{t}=0$. This has been shown to fail so a weaker requirement of "PPP in the long run" requires $\operatorname{plim}_{t \rightarrow \infty} e_{t}=0$. We note first that $e_{t}$ is stationary whenever $\rho\left(1-\lambda_{H}\right)<1$ and $\rho\left(1-\lambda_{L}\right)<1$. Clearly, this is automatically true if $\rho<1$ and $\lambda_{i} \geq 0$. Thus $e_{t}$ is stationary in the nonintervention zone only if $\rho<1$. Empirical studies often find the autocorrelation coefficient of real exchange rates to be very close to unity. Importantly, in our framework, 
$\rho=1$ is compatible with stationarity because $\lambda_{i}>0$ suffices (that is, $\theta_{H}, \theta_{L}<1$ ). The interpretation then is that systematic intervention prevents real exchange rates from drifting to large values, positive or negative, and stabilizes them in the precise sense of achieving long-run convergence. The claim of PPP in the long run requires more than this, because the convergence should be to zero. We do not know, as yet, how the non-linearity induced by intervention affects the long-run distribution of $e_{t}$. It is likely that significant asymmetries$\lambda_{L}>\lambda_{H}$ for example-may cause upward bias or long-run overvaluation.

\section{Structural parameters}

In the presence of intervention, we can estimate the reduced form parameters $\theta_{i}, \mu_{i}$. It is often important to evaluate counterfactuals. Here, in particular, how would exchange rates behave in the absence of intervention. The answer to this question depends on knowledge of the structural parameters $\beta$ and $\rho$. Unfortunately, they are not identified, because we cannot recover six structural parameters $\left(e_{H}, e_{L}, \lambda_{H}, \lambda_{L}, \beta, \rho\right)$ from five reduced-form parameters. ${ }^{8}$ However, the hypothesis $\rho=1$ is testable because $\theta_{0}=\frac{\beta+\rho}{1+\beta}$ is less than 1 if, and only if, $\rho<1$.

\section{Extent of intervention}

Some countries intervene more than others in their attempts at currency stabilization; this is the main hypothesis of "fear of floating." Can we compare the extent to which countries differ in aggressiveness? This requires estimates of $\lambda_{i}$. These parameters are not identified in this framework. However, the hypotheses $\lambda_{L}=0$ and $\lambda_{H}=0$ are testable as long as $e_{i} \neq 0$, because $\lambda_{i}=0 \Rightarrow \mu_{i}=0$ and also $\theta_{i}=\theta_{0}$. Similarly, the hypothesis of maximal intervention $\lambda_{i}=1$ implies the testable restriction $\theta_{i}=0$. The parameters $\theta_{i}$ decrease with (the magnitude of) intervention $\lambda_{i}$ since $\partial \theta_{i} / \partial \lambda_{i}=-(\beta+\rho)$. We can test for symmetry: $\lambda_{L}=\lambda_{H} \Rightarrow \theta_{L}=\theta_{H}$. International comparisons are meaningful if $\rho$ or $\beta$ can be thought to be same across similar economies.

\section{Interest rate responses}

We note that

$$
z_{t}=-\mu_{i}+\left(1-\theta_{i}\right) e_{t}
$$

Suppose the exchange rate depreciates and the government raises interest rates to defend the depreciation. Interest rates move to achieve equilibrium in asset markets. This response may

\footnotetext{
${ }^{8}$ All parameters of interest are actually identifiable in the general framework (there are seven reduced form parameters) but not in the linear approximation here which has five reduced form parameters.
} 
well be perverse $-z_{t}$ and hence $r_{t}$ fall if $\theta_{L}<1$. The intuition comes from the interest parity condition

$$
e_{t}-z_{t}=\bar{e}_{t+1}+s_{t+1}
$$

The implied correlation between $z_{t}$ and $s_{t+1}$ is negative. This does not capture the full effect because $z_{t}$ affects $\bar{e}_{t}$. Our framework estimates the total effect $\left(1-\theta_{L}\right)$ and can evaluate whether there are significant asymmetries in the effects of defending at the top and at the bottom. Interest rate effects are likely to be a major element of the costs of exchange rate intervention. This response may be different across countries because of differences in the structure of financial markets.

Real effects of intervention

Variations in $e_{t}$ are likely to affect interest rates, and hence output, in the absence of intervention. This is measured by $\left.\frac{\partial r_{t}}{\partial e_{t}}\right|_{s_{t+1}=0}=1-\theta_{0}$. In our framework, the incremental effect of interventions can be measured by

$$
\left.\eta_{i} \equiv \frac{\partial r_{t}}{\partial e_{t}}\right|_{s_{t} \neq 0}-\left.\frac{\partial r_{t}}{\partial e_{t}}\right|_{s_{t}=0}=-\theta_{i}+\theta_{0}
$$

for $i=L$ and $i=H$. This would imply that defended depreciations are expansionary if

$$
\theta_{L}>\theta_{0} \Rightarrow \eta_{L}<0
$$

Similarly, defended appreciations are contractionary if

$$
\theta_{H}<\theta_{0} \Rightarrow \eta_{H}>0
$$

\footnotetext{
${ }^{9}$ In the literature on interventions (sterilized and non-sterilized), the exchange rate is affected through a portfolio balance effect, noise trading due to asymmetric information, and a signaling effect about the stance of monetary policy.
} 


\section{Estimation AND RESUlts}

We examine real effective exchange rates for twenty seven countries, including Asian, Latin American, and industrial countries. ${ }^{10}$ The countries in our sample may be classified as floating, managed, and limited flexibility regimes, though not fixed throughout the estimation period. All data are taken from the International Financial Statistics (IFS) database of the International Monetary Fund (IMF). The real effective exchange rate (REER), based on consumer prices, measures movements in the nominal exchange rate adjusted for differentials between the domestic price index and trade-weighted foreign price indices. The IMF's CPI-based REER indicator (year 1995 $=100$ ) of country $i$ is:

$$
e_{t}=\prod_{j \neq i}\left(\frac{P_{i} R_{i}}{P_{j} R_{j}}\right)^{W_{i j}}
$$

where $j$ is an index that runs over country $i$ 's trade partners; $W_{i j}$ is the competitiveness weight put by country $i$ on country $j, P_{i}$ and $P_{j}$ are consumer price indices in countries $i$ and $j$; and $R_{i}$ and $R_{j}$ represent the nominal exchange rates of countries $i$ and $j$ 's currencies in US dollars. ${ }^{11}$ An increase (appreciation) in a country's index indicates a decline in international competitiveness.

Figure 1 shows the monthly real effective exchange rates (logarithms) for the period 1980:01 to 2001:05, the common period for the countries in the sample. A cursory examination shows that the REERs have varied substantially around the mean but not away from it for extended periods of time. In some instances (notably Japan, Israel, India, and Paraguay) the "mean" may have shifted over time. The depreciation of the REER for countries affected during the Asian crisis is clear. The descriptive statistics for percentage changes in the REER indicate that relative to the industrial countries, the series for the "non-industrial" countries (Asian and Latin American) exhibit greater variability, as measured either by the range or the standard deviation (Calvo and Reinhart (2000) find the reverse for nominal rates). Also, skewness and kurtosis are more pronounced for emerging market countries. Standard tests for unit roots show that the unit root hypothesis is rejected only for Costa Rica; Argentina also rejects the unit root null if a trend term is included in the estimating equation (see Table 1).

If governments intervene when REERs are particularly high or low, then data on REERs should contain the implicit (revealed) bands of the policy maker. Ideally, we should estimate

${ }^{10}$ The countries are: United States, United Kingdom, Germany, Japan, France, Canada, Italy, Australia, Belgium, New Zealand, Spain, Israel, South Africa, Korea, Thailand, Malaysia, Indonesia, India, Philippines, Argentina, Brazil, Chile, Colombia, Costa Rica, Mexico, Paraguay, and Uruguay.

${ }^{11}$ For a detailed methodology, see Zanello and Desruelle (1997); also, see Lafrance and St. Amant (1999). 
the temporal properties $[I(1)$ or $I(0)]$ of the series jointly with the intervention band; ${ }^{12}$ alternatively, we could estimate the temporal properties of the series conditional on specific bands. ${ }^{13}$ This latter approach, which we follow here, is computationally less burdensome, but does not provide estimates of the intervention band. In particular, the sampling distribution of our t-statistics depend on the presence of dummies and the parameters of the intervention band. However, a Monte Carlo simulation shows that the critical values of the statistics are less in absolute value than but approach the corresponding Dickey-Fuller values as the band width widens to include most observations in the sample. ${ }^{14}$ Also, we use the simple method of segmented ordinary least squares regressions. ${ }^{15}$ In implementing our test, we assume symmetry in the response bands $(\bar{x} \pm \kappa \sigma)$, where $\kappa$ ranges from 0.25 to 1.00 , in increments of $0.25^{16}$

We estimate equations 1 and 2 below using two methods. All results are estimated on 1981:03 to 2001:05, using Eviews 4.0. Given the heteroscedasticity results in Cashin and McDermott (2001) on essentially the same span of data, we first estimate the equation using the Newey-West correction for unknown heteroscedasticity and autocorrelation (HAC). The truncation lag, as in the Phillips-Perron unit root test above, is based on the number of observations. ${ }^{17}$ The $H A C$ results are presented in Table 2 . Second, we select the number of lags required to adjust for serial correlation and report t-statistics based on White's heteroscedastic-consistent standard errors $(W H C)$. These results are reported in Table 3 . In

${ }^{12}$ One way of doing this is to model the intervention bands as regimes in a Markov-switching model or in a smooth transition regression (see Hamilton (1989), Tong (1990), and Granger and Teräsvirta (1993)).

${ }^{13}$ We can think of this process as generating close approximations for estimates of a nonlinear model, whose likelihood function has been partitioned into two sets such that the estimates of one set of parameters are a function of the values of the other set (in our case, the intervention bandwidth).

${ }^{14}$ We estimate our regressions on a sample of 240 observations, generated from a random walk with starting value of $\ln (100)$ and iid errors (5000 iterations). The simulated distributions for each $t$-statistic are evaluated on a partial grid ranging from -3 to 0 . Joint F-tests are also tabulated.

${ }^{15}$ Our regimes are classified as discrete shifts - policy intervention in monthly data is probably less affected by time aggregation and nonsynchronous adjustment by agents, factors which favor smooth rather than discrete adjustment (Teräsvirta (1994)).

${ }^{16}$ The maximum value of 1.00 was based on the number of observations in progressively larger bands across all countries in the sample.

${ }^{17}$ The lag $q$ is the largest integer not exceeding $q=$ floor $\left(4(\mathrm{~T} / 100)^{2 / 3}\right)$; in our case, 4 . 
choosing the number of lags, the test equation for each $K$ was estimated with up to a maximum of 12 lags of the dependent variable and the lag length that minimized the Akaike Information Criterion ( $A I C$ ) was recorded as $l \kappa$. The estimates reported in Table 3 are for the equation with the minimum $A I C$ across the values of $\kappa$, that is $\min l_{\kappa}$.

An alternative to the minimum $A I C$ procedure is the iterative procedure recommended by $\mathrm{Ng}$ and Perron (1995) (see also Lütkepohl (1993)). For that procedure, starting from a maximum lag of 12, we test for the significance of the coefficient on the $12^{\text {th }}$ lag of the dependent variable $\left(\Delta e_{t}\right)$. If it is insignificant, we drop that lag, re-estimate the regression, and continue testing until the coefficient on the $p t h$ lag is significantly different from zero. All lags up to $p$ are retained in the test equation. A maximum likelihood-based choice of $\kappa$ may be ambiguous because (1) lags based on $O L S$ standard errors will typically differ from lags based on heteroscedastic-consistent standard errors, but the equation diagnostics (e.g., standard error, likelihood) for the same number of lags will be identical, and (2) a longer lag at $\kappa_{1}$ may have a higher likelihood than a shorter lag at $\kappa_{2}$, even if the likelihood at $\kappa_{2}$ for the same number of lags as at $\kappa_{1}$ was higher. We implemented that procedure and found similar results to those of the minimum $A I C$ procedure except for two cases; we have not reported the results here, but they are available on request.

Our estimating equation for $H A C$ is: ${ }^{18}$

$$
\Delta e_{t}=\beta_{0}+\beta_{1} D_{L}+\beta_{2} D_{H}+\beta_{3} e_{t-1}+\beta_{4} e_{t-1} D_{L, t-1}+\beta_{5} e_{t-1} D_{H, t-1}+\varepsilon_{t}
$$

and for $W H C$ :

$$
\begin{aligned}
\Delta e_{t}= & \beta_{0}+\beta_{1} D_{L}+\beta_{2} D_{H}+\beta_{3} e_{t-1}+\beta_{4} e_{t-1} D_{L, t-1}+\beta_{5} e_{t-1} D_{H, t-1} \\
& +\sum_{j=1}^{p}\left(\gamma_{j}+\varphi_{j} D_{L, t-j}+\pi_{j} D_{H, t-j}\right) \Delta e_{t-j}+\varepsilon_{t}
\end{aligned}
$$

where $D_{L}$ and $D_{H}$ are indicator variables that take the value 1 when observations are outside the non-intervention bands $\bar{x} \pm \kappa \sigma$.

From (E.1) - (E.3),

$$
\begin{aligned}
& \beta_{1}=\mu_{L} ; \beta_{2}=\mu_{H} \\
& \theta_{0}=1+\beta_{3} ; \theta_{L}=1+\beta_{3}+\beta_{4} ; \theta_{H}=1+\beta_{3}+\beta_{5}
\end{aligned}
$$

\footnotetext{
${ }^{18}$ We do not include a trend variable; it is not consistent with long-run PPP and, with a few exceptions, is not supported by the initial unit root tests. When included, the rationale is to control for the Balassa-Samuelson effect (see Cashin and McDermott, 2001).
} 
$\beta_{4}$ and $\beta_{5}$ can be interpreted as the speed of adjustment toward the intervention thresholds. As $\beta_{4}$ and $\beta_{5}$ increase, the speed of adjustment increases. Their significance is important because the power to detect a unit root can depend on the size of $\beta_{4}$ and $\beta_{5}$, the size of the intervention band, and the variance of the process. Specifically, Pippenger and Goering (1993) show that the power to detect reversion declines the slower the speed of adjustment (the smaller is $\beta_{4}$ and $\beta_{5}$ ) and the larger the intervention band.

We summarize our results, based on Table 2, according to the following hypotheses:

No effective intervention

$$
\begin{aligned}
& \theta_{L}=\theta_{0} \Rightarrow \beta_{4}=0 \\
& \theta_{H}=\theta_{0} \Rightarrow \beta_{5}=0
\end{aligned}
$$

The hypothesis of no effective intervention at the lower bound $\left(\beta_{4}=0\right)$ is rejected almost universally. $\beta_{4}$ is significant for all advanced countries, except Spain and for all emerging market countries, except Korea, with Argentina, Malaysia, and Costa Rica having the lowest level of significance. The hypothesis of no effective intervention at the upper bound $\left(\beta_{5}=0\right)$ is rejected for all advanced economies, with Australia and the United Kingdom having the lowest levels of significance; for the emerging market countries, $\beta_{5}$ is significant in eight countries, with Malaysia and Brazil having the lowest level of significance. Canada and Malaysia are the only countries that do not reject the joint hypothesis of no effective intervention $\left(\beta_{4}=\beta_{5}=0\right.$, shown as $F_{I N}$ in Tables 2 and 3).

\section{Stationarity}

$$
\rho<1 \Rightarrow 1+\beta_{3}<1 \Rightarrow \beta_{3}<0
$$

Four of the 12 advanced countries and 9 of the 15 emerging markets do not reject the unit root null in the middle regime. In every case, the Dickey-Fuller specification is rejected against the test equation. This result $\left(\beta_{1}=\beta_{2}=\beta_{4}=\beta_{5}=0\right)$ is reported in Tables 2 and 3 as $F_{D F}$. For the standard Dickey-Fuller specification, the Dickey-Fuller test (adjusted for heteroscedasticity and autocorrelation) does not reject the unit root null in every case. This result is shown in parentheses in the column $F_{D F}$ below each $F$-value. If only the intercept is regime specific (common autoregressive coefficient), then among the advanced countries only the United States and Italy would not reject the unit root hypothesis (using standard Dickey-Fuller critical values); of the emerging market countries, five would not reject. This result is reported in parentheses in the column for $F_{I N}$ below each $F$-value. 
Defended depreciations are expansionary, and defended appreciations contractionary:

$$
\begin{aligned}
& \theta_{L}>\theta_{0} \Rightarrow \beta_{4}>0 \\
& \theta_{H}<\theta_{0} \Rightarrow \beta_{5}<0
\end{aligned}
$$

Where $\beta_{4}$ and/or $\beta_{5}$ are significant, the evidence favors expansionary effects for defended depreciations and contractionary effects for defended appreciations. However, we need view this result with caution, because we do not estimate the direct impact of an exchange rate defense on output or on real interest rates. We develop the empirical hypothesis from the assumption that interest rates fully anticipate policy intervention: this can fail if there are systematic departures from interest parity during periods of intervention, because policy surprises are not reflected in real interest rate responses. ${ }^{19}$

\section{General observations}

The results for Table 3 reflect similar patterns, with some results even stronger, suggesting some robustness to the conclusions. For example, only two advanced countries (Japan and Italy) and six emerging countries do not reject the unit root null. The Dickey-Fuller specification is rejected against the test equation for all countries except Malaysia and the Dickey-Fuller test (adjusted for heteroscedasticity and autocorrelation) does not reject the unit root null for all countries except Costa Rica and Mexico. As regards the intervention results, only Spain has an insignificant $\beta_{4}$ among the advanced countries; for the emerging market countries, $\beta_{4}$ is insignificant for four countries (Indonesia, Korea, Malaysia, and Argentina). $\beta_{5}$ is insignificant for three of the advanced countries (United States, Canada, and Italy) but insignificant for eight of the 15 emerging countries. Similarly, all advanced countries reject the unit root null if the intercept is regime-specific, and only three emerging market countries do not reject.

The results indicate that both the intercept and the autoregressive terms in the estimating regression are regime specific, but more accurate joint estimation of the intervention band and the lag structure may be desirable. Our results also indicate much lower half-lives of shocks than the consensus estimates of three to five years. ${ }^{20}$ For the advanced countries, point

\footnotetext{
${ }^{19}$ Using the daily overnight Eurocurrency rate, Baillie and Osterberg (2000) find limited evidence of a significant impact of intervention on the conditional mean of deviations from uncovered interest rate parity (UIP). However, Eichenbaum and Evans (1995) show monetary policy leads to persistent departures from UIP.

${ }^{20}$ The half-live is the length of time it takes for a unit impulse to dissipate by half. It is calculated using $H L=a b s(\log (0.5) / \log (\beta))$, where $\beta$ is the autoregressive parameter (Cashin and McDermott, 2001). For a half-life larger than three years, the point estimates of $\beta$ need to be less than 0.02 in absolute value.
} 
estimates for the non-intervention range suggest half-lives ranging from 4 months (United Kingdom, New Zealand, Israel) to about 17 months (United States); for the emerging countries, the estimates of the half-lives of shocks are less than twelve months for all countries except India, Chile, and Columbia. In general, the non-intervention bands for the advanced economies are narrower and more symmetric than those for the emerging market economies, and the dynamics of the processes differ - for example, the coefficients on the lagged dependent variables interacted with the intervention thresholds are jointly significant for most emerging countries, but less so for the advanced countries. Further, as the intervention band increases, we do not reject the unit root null with greater frequency, ${ }^{21}$ suggesting that the typical finding of a unit root may be because the series comprise two components, one of which is nonstationary, ${ }^{22}$ or because the standard unit root test is strongly influenced by extreme observations.

\section{FURTher IsSUES}

Nobay and Peel (1997) argue that evidence of random walk behavior for small deviations but fast adjustment for large deviations from PPP may be due to nonlinearity in the adjustment process. Similarly, Kilian and Taylor (2001) propose a nonlinear model that implies random walk behavior near equilibrium but mean-reverting behavior for large departures from fundamentals. We argue that this behavior is also consistent with intervention by the authorities. Our results, which may be viewed as demonstrating some empirical characteristics rather than "finding the true DGP," suggests that (a) a "fear of depreciation" is an almost universal phenomenon among both advanced and emerging market countries; (b) the hypothesis that real effective exchange rates have a unit root is not robust to nonlinear specifications; and (c) the measurement of the effect of intervention on real exchange rates is not symmetric and that asymmetry differs across countries.

Specifically, we do not reject the unit root null almost universally, when we impose no intervention or a single-regime model (standard ADF test), explaining the results of earlier studies. We reject the unit root null almost universally, when we allow only the mean to be regime specific (even when the restriction of no intervention is false). Thus our results are also consistent with the finding of Bergman and Hansson (2000). However, our estimation technique may be improved by nonlinear estimation or use of smooth transition autoregression (STAR) models. For example, Silverstovs (2000) proposed a bi-parameter STAR model that estimates two threshold parameters and two adjustment parameters in a three-regime setting.

${ }^{21}$ Estimates of $\beta_{3}$ are generally stable for different lag lengths but $\beta_{3}$ appears concave with respect to $\kappa$ (bandwidth), tending to decrease (not reject unit root) as $\kappa$ increases.

${ }^{22}$ Engel (2000) proposes a similar decomposition but based on traded/nontraded goods dichotomy. 
At present, we seek to demonstrate the nature of interventions, and the extent to which they vary across countries. Our most significant finding is the "dread of depreciation" in emerging market economies; the natural question is why. We can only speculate, but alternative hypotheses have clear empirical counterparts. This finding is somewhat of a puzzle because many emerging market economies are exporters, and depreciations are likely to stimulate net exports. At the same time, they raise the real cost of servicing debt denominated in foreign currency, and can trigger bankruptcies among firms that hold such debt. Thus, defending large depreciations are one sort of coordinated bail-out. This type of intervention is likely to lower interest rate differentials, and the real cost of domestic borrowing, as we show. In consequence, the net cost of intervention may be asymmetric, and lower defenses seen as cheaper than upper ones. The financial channel may be an important factor in policy intentions; it also provides a mechanism by which the need for systematic intervention becomes self-fulfilling. If governments defend depreciation below a tolerance level, firms rationally expect exchange rates to be above this level most of the time, and so discount the potential costs of servicing foreign currency debt. If the currency does actually depreciate, the possibility of substantial bankruptcies can trigger a defense and fulfill policy expectations.

Our analysis associates intervention with nonlinearities in the autoregression

$$
E e_{t+1}=\phi\left(e_{t}\right)
$$

While this is derived from a very specific hypothesis about the intention of policy, this evidence can be consistent with other hypotheses about the behavior of exchange rates. ${ }^{23} \mathrm{An}$ important alternative hypothesis comes from Michael and others (1997), that transactions costs in goods trading results in range reversion rather than mean reversion. They estimate their model by imposing exponential threshold autoregression (ETAR). That hypothesis imposes symmetry; as we show, this is very often a bad fit. Nevertheless, some variation of the transaction cost model can lead to a reduced form similar to ours. ${ }^{24}$ Specifically, Calvo and Reinhart's (2000) reasons for a fear of floating can be thought of as costs which determine the bands within which policy makers are less likely to undertake policy interventions. ${ }^{25}$ It is possible to discriminate between the two hypothesis, in an extended

${ }^{23}$ For example, the contention that the U.S. targets the REER may seem unwarranted (see Eichenbaum and Evans (1995) who find that in the US monetary policy leads to persistent changes in exchange rates, nominal and real). For a preliminary comparison, we ran our regressions using the nominal effective exchange rate as the dependent variable and found the coefficients $\beta_{4}$ and $\beta_{5}$ even more statistically significant.

${ }^{24}$ Obstfeld and Rogoff (2000) argue that transaction costs may account for most current puzzles in international macroeconomics.

${ }^{25}$ Calvo and Reinhart(2000) list the following reasons for a fear of floating: lack of credibility; debt servicing; inflation pass-through from exchange rate swings; greater adverse output effects of devaluations; loss of competitiveness, and loss of access to capital markets. 
framework where we observe instruments $s_{t}$. This is clearly an important direction of future research.

We assume that UIP holds at each $t$, and solve for the rational expectations equilibrium path. Evidence presented by Eichenbaum and Evans (1995) suggests that interest parity fails in periods of exchange rate intervention. An enriched model can be used to quantify this, and refine our estimate of the costs of intervention. Failures of interest parity are particularly important in tracking the real effects of intervention as we suggest earlier.

In this paper, we do not track instrument use. This is clearly a priority in further analysis, as is the measurement of the real effects of (mis)management of exchange rates. Also, we concentrate on the effects on $e_{t}$ and the implied effect on $r_{t}$. Changes in interest rates have non-negligible effects on investment and output, so that exchange rate interventions generate output cost in addition to the direct impact of the real exchange rate itself. These effects can be mediated by more than one channel; firms react to changes in the price of exported output and imported inputs; the importance of the financial channel has been emphasized especially since the Asia crisis. A careful evaluation of their quantitative importance, and the incremental role of anticipated interventions, is clearly a question needing further attention. The work of Campa and Goldberg (1999) suggest that there are important differences between countries in the effect of exchange rates on output and investment; our model provides one reason why this may be the case. We conclude with the following question. Observe that for $\lambda=0$ (no intervention), $\rho=1$ implies a random walk process $(\theta=1)$. In just the same way that the unit root hypothesis is not robust to nonlinearity, could it also be that the "exchange rate disconnect" hypothesis is also not robust to nonlinearity? 
Table 1. Tests for Unit Roots, 1981:03-2001:05

\begin{tabular}{|c|c|c|c|c|}
\hline & \multicolumn{2}{|c|}{ ADF } & \multicolumn{2}{|c|}{ Phillips-Perron } \\
\hline & Intercept & $\begin{array}{c}\text { Intercept and } \\
\text { Trend }\end{array}$ & Intercept & $\begin{array}{c}\text { Intercept and } \\
\text { Trend } \\
\end{array}$ \\
\hline & \multicolumn{4}{|c|}{ Advanced Economies - G7 } \\
\hline United States & -1.07 & -0.92 & -1.05 & -0.91 \\
\hline United Kingdom & -2.46 & -2.61 & -2.32 & -2.50 \\
\hline Germany & -1.65 & -1.44 & -1.72 & -1.53 \\
\hline Japan & -1.56 & -2.00 & -1.52 & -1.89 \\
\hline France & -1.83 & -1.97 & -1.92 & -2.06 \\
\hline Canada & -0.88 & -2.65 & -0.70 & -2.58 \\
\hline \multirow[t]{2}{*}{ Italy } & -1.67 & -1.80 & -1.59 & -1.73 \\
\hline & \multicolumn{4}{|c|}{ Other Advanced Economies } \\
\hline Australia & -1.44 & -2.45 & -1.56 & -2.61 \\
\hline New Zealand & -1.86 & -1.79 & -1.95 & -1.89 \\
\hline Spain & -1.32 & -1.19 & -1.31 & -1.19 \\
\hline Belgium & -2.16 & -2.29 & -2.06 & -2.20 \\
\hline \multirow[t]{2}{*}{ Israel } & -1.65 & -2.54 & -2.18 & -3.12 \\
\hline & \multicolumn{4}{|c|}{ Emerging Countries } \\
\hline India & -1.39 & -0.10 & -1.39 & -0.15 \\
\hline Indonesia & -1.30 & -2.76 & -1.32 & -2.78 \\
\hline Korea & -2.14 & -2.73 & -2.24 & -2.85 \\
\hline Malaysia & -1.15 & -2.45 & -1.03 & -2.18 \\
\hline Philippines & -2.20 & -2.43 & -2.07 & -2.27 \\
\hline Thailand & -1.43 & -2.98 & -1.41 & -2.88 \\
\hline South Africa & -1.70 & -2.36 & -2.02 & -2.78 \\
\hline Argentina & -1.74 & -3.72 & -1.92 & -3.83 \\
\hline Brazil & -1.86 & -1.84 & -2.07 & -2.05 \\
\hline Chile & -2.42 & -1.92 & -2.32 & -1.71 \\
\hline Colombia & -1.51 & -1.12 & -1.40 & -1.00 \\
\hline Costa Rica & -3.72 & -3.88 & -3.43 & -3.62 \\
\hline Mexico & -1.99 & -2.28 & -2.14 & -2.44 \\
\hline Paraguay & -2.21 & -2.32 & -2.21 & -2.32 \\
\hline Uruguay & -1.45 & -2.09 & -1.47 & -2.13 \\
\hline
\end{tabular}

Note: The lag truncation for the Phillips-Perron is 4, based on the Newey-West estimator; for comparison, the $\mathrm{ADF}$ values are also based on 4 lags of the dependent variable. Five percent critical value for the column 'intercept' is -2.87 ; for 'intercept and trend' it is -3.43 (finite sample critical values based on MacKinnon, 1991). 
Table 2. Estimates Based on HAC Correction, 1981:03-2001:05

\begin{tabular}{|c|c|c|c|c|c|c|c|c|c|}
\hline & $\sigma$ & $\beta_{0}$ & $\beta_{1}$ & $\beta_{2}$ & $\beta_{3}$ & $\beta_{4}$ & $\beta_{5}$ & $F_{D F}$ & $F_{I N}$ \\
\hline \multicolumn{10}{|c|}{ Advanced Economies - G7 } \\
\hline United States & 0.25 & $\begin{array}{c}0.17 \\
(1.47)\end{array}$ & $\begin{array}{c}-0.02 \\
(4.43)\end{array}$ & $\begin{array}{c}0.03 \\
(5.09)\end{array}$ & $\begin{array}{c}-0.04 \\
(1.47)\end{array}$ & $\begin{array}{c}0.004 \\
(4.50)\end{array}$ & $\begin{array}{r}-0.004 \\
(3.93)\end{array}$ & $\begin{array}{c}10.81 \\
(0.49)\end{array}$ & $\begin{array}{r}12.86 \\
(2.74)\end{array}$ \\
\hline United Kingdom & 0.75 & $\begin{array}{c}0.78 \\
(4.67)\end{array}$ & $\begin{array}{l}-0.05 \\
(5.62)\end{array}$ & $\begin{array}{c}0.03 \\
(5.80)\end{array}$ & $\begin{array}{c}-0.17 \\
(4.68)\end{array}$ & $\begin{array}{c}0.006 \\
(4.11)\end{array}$ & $\begin{array}{l}-0.002 \\
(2.10)\end{array}$ & $\begin{array}{l}24.45 \\
(1.95)\end{array}$ & $\begin{array}{c}9.26 \\
(6.15)\end{array}$ \\
\hline Germany & 0.50 & $\begin{array}{c}0.54 \\
(3.90)\end{array}$ & $\begin{array}{c}-0.02 \\
(7.11)\end{array}$ & $\begin{array}{c}0.01 \\
(8.57)\end{array}$ & $\begin{array}{c}-0.12 \\
(3.90)\end{array}$ & $\begin{array}{l}0.002 \\
(3.95)\end{array}$ & $\begin{array}{r}-0.001 \\
(4.16)\end{array}$ & $\begin{array}{r}18.42 \\
(1.22)\end{array}$ & $\begin{array}{c}8.52 \\
(6.42)\end{array}$ \\
\hline Japan & 0.25 & $\begin{array}{c}0.22 \\
(1.66)\end{array}$ & $\begin{array}{c}-0.06 \\
(8.20)\end{array}$ & $\begin{array}{c}0.04 \\
(6.53)\end{array}$ & $\begin{array}{c}-0.05 \\
(1.65)\end{array}$ & $\begin{array}{c}0.01 \\
(6.56)\end{array}$ & $\begin{array}{c}-0.01 \\
(4.88)\end{array}$ & $\begin{array}{c}15.18 \\
(1.03)\end{array}$ & $\begin{array}{c}17.74 \\
(3.48)\end{array}$ \\
\hline France & 0.50 & $\begin{array}{c}0.59 \\
(3.07)\end{array}$ & $\begin{array}{c}-0.01 \\
(7.21)\end{array}$ & $\begin{array}{c}0.01 \\
(4.29)\end{array}$ & $\begin{array}{c}-0.13 \\
(3.07)\end{array}$ & $\begin{array}{l}0.001 \\
(3.26)\end{array}$ & $\begin{array}{r}-0.002 \\
(3.33)\end{array}$ & $\begin{array}{l}24.02 \\
(1.58)\end{array}$ & $\begin{array}{l}11.36 \\
(4.52)\end{array}$ \\
\hline Canada & 0.50 & $\begin{array}{c}0.56 \\
(3.82)\end{array}$ & $\begin{array}{c}-0.04 \\
(19.39)\end{array}$ & $\begin{array}{c}0.02 \\
(5.80)\end{array}$ & $\begin{array}{c}-0.12 \\
(3.82)\end{array}$ & $\begin{array}{l}0.005 \\
(7.22)\end{array}$ & $\begin{array}{l}-0.002 \\
(2.43)\end{array}$ & $\begin{array}{c}9.78 \\
(0.38)\end{array}$ & $\begin{array}{c}2.85 \\
(4.52)\end{array}$ \\
\hline Italy & 0.75 & $\begin{array}{c}0.51 \\
(2.34)\end{array}$ & $\begin{array}{c}-0.02 \\
(6.16)\end{array}$ & $\begin{array}{c}0.03 \\
(3.09)\end{array}$ & $\begin{array}{c}-0.11 \\
(2.33)\end{array}$ & $\begin{array}{c}0.002 \\
(3.15)\end{array}$ & $\begin{array}{l}-0.004 \\
(2.35)\end{array}$ & $\begin{array}{r}13.54 \\
(0.83)\end{array}$ & $\begin{array}{c}6.51 \\
(2.79)\end{array}$ \\
\hline \multicolumn{10}{|c|}{ Other Advanced Economies } \\
\hline Australia & 0.75 & $\begin{array}{c}0.57 \\
(4.11)\end{array}$ & $\begin{array}{c}-0.04 \\
(6.34)\end{array}$ & $\begin{array}{c}0.05 \\
(4.16)\end{array}$ & $\begin{array}{c}-0.12 \\
(4.11)\end{array}$ & $\begin{array}{c}0.004 \\
(2.99)\end{array}$ & $\begin{array}{l}-0.004 \\
(2.05)\end{array}$ & $\begin{array}{c}14.74 \\
(1.24)\end{array}$ & $\begin{array}{c}6.38 \\
(6.04)\end{array}$ \\
\hline New Zealand & 0.50 & $\begin{array}{c}0.77 \\
(4.76)\end{array}$ & $\begin{array}{l}-0.04 \\
(5.41)\end{array}$ & $\begin{array}{c}0.03 \\
(8.09)\end{array}$ & $\begin{array}{c}-0.17 \\
(4.75)\end{array}$ & $\begin{array}{l}0.004 \\
(3.24)\end{array}$ & $\begin{array}{c}-0.003 \\
(3.66)\end{array}$ & $\begin{array}{l}22.55 \\
(1.52)\end{array}$ & $\begin{array}{c}7.55 \\
(5.95)\end{array}$ \\
\hline Spain & 0.75 & $\begin{array}{c}0.25 \\
(2.11)\end{array}$ & $\begin{array}{c}-0.04 \\
(1.69)\end{array}$ & $\begin{array}{c}0.04 \\
(6.40)\end{array}$ & $\begin{array}{r}-0.06 \\
(2.11)\end{array}$ & $\begin{array}{l}0.008 \\
(1.47)\end{array}$ & $\begin{array}{r}-0.006 \\
(6.78)\end{array}$ & $\begin{array}{l}19.45 \\
(0.80)\end{array}$ & $\begin{array}{l}22.97 \\
(2.94)\end{array}$ \\
\hline Belgium & 0.25 & $\begin{array}{c}0.39 \\
(3.49)\end{array}$ & $\begin{array}{c}-0.01 \\
(3.55)\end{array}$ & $\begin{array}{c}0.01 \\
(5.25)\end{array}$ & $\begin{array}{c}-0.08 \\
(3.49)\end{array}$ & $\begin{array}{c}0.002 \\
(2.67)\end{array}$ & $\begin{array}{l}-0.002 \\
(4.61)\end{array}$ & $\begin{array}{c}19.22 \\
(1.84)\end{array}$ & $\begin{array}{l}17.73 \\
(3.85)\end{array}$ \\
\hline Israel & 0.25 & $\begin{array}{c}0.77 \\
(4.73)\end{array}$ & $\begin{array}{l}-0.03 \\
(6.25)\end{array}$ & $\begin{array}{c}0.03 \\
(8.08)\end{array}$ & $\begin{array}{c}-0.17 \\
(4.73)\end{array}$ & $\begin{array}{l}0.004 \\
(4.87)\end{array}$ & $\begin{array}{l}-0.004 \\
(3.66)\end{array}$ & $\begin{array}{c}40.6 \\
(2.01)\end{array}$ & $\begin{array}{l}20.36 \\
(6.20)\end{array}$ \\
\hline \multicolumn{10}{|c|}{ Emerging Countries } \\
\hline India & 0.5 & $\begin{array}{c}0.08 \\
(1.13)\end{array}$ & $\begin{array}{c}-0.17 \\
(24.16)\end{array}$ & $\begin{array}{c}0.02 \\
(4.10)\end{array}$ & $\begin{array}{c}-0.02 \\
(1.25)\end{array}$ & $\begin{array}{c}0.04 \\
(25.07)\end{array}$ & $\begin{array}{c}-0.002 \\
(1.78)\end{array}$ & $\begin{array}{l}27.36 \\
(1.48)\end{array}$ & $\begin{array}{c}48.27 \\
(1.48)\end{array}$ \\
\hline Indonesia & 1 & $\begin{array}{c}0.57 \\
(3.07)\end{array}$ & $\begin{array}{c}-0.19 \\
(3.41)\end{array}$ & $\begin{array}{c}0.15 \\
(3.17)\end{array}$ & $\begin{array}{c}-0.12 \\
(3.08)\end{array}$ & $\begin{array}{c}0.03 \\
(2.87)\end{array}$ & $\begin{array}{l}-0.01 \\
(1.20)\end{array}$ & $\begin{array}{c}12.34 \\
(0.95)\end{array}$ & $\begin{array}{c}5.46 \\
(3.64)\end{array}$ \\
\hline Korea & 0.75 & $\begin{array}{c}0.52 \\
(2.59)\end{array}$ & $\begin{array}{c}-0.1 \\
(1.82)\end{array}$ & $\begin{array}{c}0.02 \\
(5.29)\end{array}$ & $\begin{array}{c}-0.11 \\
(2.60)\end{array}$ & $\begin{array}{c}0.02 \\
(1.45)\end{array}$ & $\begin{array}{l}-0.001 \\
(1.75)\end{array}$ & $\begin{array}{l}17.15 \\
(1.31)\end{array}$ & $\begin{array}{l}20.62 \\
(4.69)\end{array}$ \\
\hline Malaysia & 0.75 & $\begin{array}{c}0.41 \\
(2.67)\end{array}$ & $\begin{array}{c}-0.04 \\
(2.74)\end{array}$ & $\begin{array}{c}0.05 \\
(14.97)\end{array}$ & $\begin{array}{c}-0.09 \\
(2.68)\end{array}$ & $\begin{array}{l}0.005 \\
(2.07)\end{array}$ & $\begin{array}{r}-0.003 \\
(2.01)\end{array}$ & $\begin{array}{c}8.51 \\
(0.76)\end{array}$ & $\begin{array}{c}3.23 \\
(3.24)\end{array}$ \\
\hline Philippines & 0.25 & $\begin{array}{c}0.38 \\
(2.46)\end{array}$ & $\begin{array}{c}-0.04 \\
(4.17)\end{array}$ & $\begin{array}{c}0.1 \\
(5.49)\end{array}$ & $\begin{array}{c}-0.08 \\
(2.49)\end{array}$ & $\begin{array}{l}0.008 \\
(3.49)\end{array}$ & $\begin{array}{l}-0.02 \\
(4.52)\end{array}$ & $\begin{array}{l}34.86 \\
(1.63)\end{array}$ & $\begin{array}{l}37.91 \\
(3.08)\end{array}$ \\
\hline Thailand & 1.25 & $\begin{array}{c}0.34 \\
(2.08)\end{array}$ & $\begin{array}{l}-0.05 \\
(4.13)\end{array}$ & $\begin{array}{c}0.07 \\
(2.08)\end{array}$ & $\begin{array}{c}-0.07 \\
(2.08)\end{array}$ & $\begin{array}{l}0.008 \\
(3.91)\end{array}$ & $\begin{array}{l}-0.01 \\
(1.45)\end{array}$ & $\begin{array}{l}14.33 \\
(0.70)\end{array}$ & $\begin{array}{r}11.47 \\
(2.89)\end{array}$ \\
\hline South Africa & 0.75 & $\begin{array}{c}0.75 \\
(3.41)\end{array}$ & $\begin{array}{c}-0.1 \\
(5.41)\end{array}$ & $\begin{array}{c}0.06 \\
(6.42) \\
\end{array}$ & $\begin{array}{c}-0.16 \\
(3.42)\end{array}$ & $\begin{array}{c}0.01 \\
(3.75)\end{array}$ & $\begin{array}{l}-0.002 \\
(0.85)\end{array}$ & $\begin{array}{l}24.15 \\
(1.61)\end{array}$ & $\begin{array}{l}15.83 \\
(4.14)\end{array}$ \\
\hline
\end{tabular}


Table 2 (concluded). Estimates Based on HAC Correction, 1981:03-2001:05

\begin{tabular}{|c|c|c|c|c|c|c|c|c|c|}
\hline & $\sigma$ & $\beta_{0}$ & $\beta_{1}$ & $\beta_{2}$ & $\beta_{3}$ & $\beta_{4}$ & $\beta_{5}$ & $F_{D F}$ & $F_{I N}$ \\
\hline \multicolumn{10}{|c|}{ Emerging Countries (continued) } \\
\hline Argentina & 0.50 & $\begin{array}{c}0.98 \\
(3.77)\end{array}$ & $\begin{array}{c}-0.15 \\
(5.02)\end{array}$ & $\begin{array}{c}0.14 \\
(4.09)\end{array}$ & $\begin{array}{c}-0.2 \\
(3.76)\end{array}$ & $\begin{array}{c}0.01 \\
(1.98)\end{array}$ & $\begin{array}{l}-0.02 \\
(2.96)\end{array}$ & $\begin{array}{l}14.78 \\
(1.40)\end{array}$ & $\begin{array}{c}7.06 \\
(4.44)\end{array}$ \\
\hline Brazil & 0.25 & $\begin{array}{c}0.9 \\
(4.46)\end{array}$ & $\begin{array}{c}-0.11 \\
(3.22)\end{array}$ & $\begin{array}{c}0.09 \\
(4.55)\end{array}$ & $\begin{array}{c}-0.21 \\
(4.46)\end{array}$ & $\begin{array}{c}0.02 \\
(2.11)\end{array}$ & $\begin{array}{l}-0.01 \\
(2.25)\end{array}$ & $\begin{array}{l}42.57 \\
(1.77)\end{array}$ & $\begin{array}{l}20.15 \\
(4.42)\end{array}$ \\
\hline Chile & 0.50 & $\begin{array}{c}0.08 \\
(0.47)\end{array}$ & $\begin{array}{c}-0.03 \\
(4.57)\end{array}$ & $\begin{array}{c}0.2 \\
(15.73)\end{array}$ & $\begin{array}{c}-0.02 \\
(0.48)\end{array}$ & $\begin{array}{l}0.006 \\
(4.00)\end{array}$ & $\begin{array}{c}-0.04 \\
(14.43)\end{array}$ & $\begin{array}{l}15.17 \\
(1.31)\end{array}$ & $\begin{array}{l}25.97 \\
(1.76)\end{array}$ \\
\hline Colombia & 0.50 & $\begin{array}{c}0.09 \\
(0.81)\end{array}$ & $\begin{array}{c}-0.04 \\
(8.59)\end{array}$ & $\begin{array}{c}0.03 \\
(2.25)\end{array}$ & $\begin{array}{c}-0.02 \\
(0.82)\end{array}$ & $\begin{array}{l}0.007 \\
(7.68)\end{array}$ & $\begin{array}{l}-0.005 \\
(1.79)\end{array}$ & $\begin{array}{c}8.32 \\
(1.19)\end{array}$ & $\begin{array}{l}11.74 \\
(2.52)\end{array}$ \\
\hline Costa Rica & 0.50 & $\begin{array}{c}0.75 \\
(3.31)\end{array}$ & $\begin{array}{c}-0.1 \\
(2.52)\end{array}$ & $\begin{array}{c}0.04 \\
(8.90)\end{array}$ & $\begin{array}{c}-0.16 \\
(3.32)\end{array}$ & $\begin{array}{c}0.02 \\
(2.17)\end{array}$ & $\begin{array}{r}-0.003 \\
(3.28)\end{array}$ & $\begin{array}{c}25.2 \\
(2.25)\end{array}$ & $\begin{array}{l}26.74 \\
(4.15)\end{array}$ \\
\hline Mexico & 0.25 & $\begin{array}{c}0.46 \\
(2.45)\end{array}$ & $\begin{array}{c}-0.11 \\
(3.50)\end{array}$ & $\begin{array}{c}0.09 \\
(4.46)\end{array}$ & $\begin{array}{c}-0.1 \\
(2.44)\end{array}$ & $\begin{array}{c}0.02 \\
(2.92)\end{array}$ & $\begin{array}{c}-0.02 \\
(3.73)\end{array}$ & $\begin{array}{l}36.17 \\
(1.68)\end{array}$ & $\begin{array}{l}44.01 \\
(2.69)\end{array}$ \\
\hline Paraguay & 0.25 & $\begin{array}{c}0.39 \\
(2.88)\end{array}$ & $\begin{array}{c}-0.09 \\
(3.84)\end{array}$ & $\begin{array}{c}0.11 \\
(4.05)\end{array}$ & $\begin{array}{c}-0.08 \\
(2.91)\end{array}$ & $\begin{array}{c}0.02 \\
(3.32)\end{array}$ & $\begin{array}{l}-0.02 \\
(3.06)\end{array}$ & $\begin{array}{l}32.41 \\
(1.81)\end{array}$ & $\begin{array}{c}40.1 \\
(3.30)\end{array}$ \\
\hline Uruguay & 0.75 & $\begin{array}{c}0.52 \\
(2.57)\end{array}$ & $\begin{array}{c}-0.08 \\
(3.42) \\
\end{array}$ & $\begin{array}{c}0.28 \\
(1.54)\end{array}$ & $\begin{array}{c}-0.1 \\
(2.54)\end{array}$ & $\begin{array}{c}0.01 \\
(2.99) \\
\end{array}$ & $\begin{array}{l}-0.05 \\
(1.41)\end{array}$ & $\begin{array}{c}61.8 \\
(0.91)\end{array}$ & $\begin{array}{r}62.25 \\
(1.83)\end{array}$ \\
\hline
\end{tabular}

Note: The results for this table are from least squares estimates of equation (1), $\Delta e_{t}=\beta_{0}+\beta_{1} D_{L}+\beta_{2} D_{H}+\beta_{3} e_{t-1}+\beta_{4} e_{t-1} D_{L, t-1}+\beta_{5} e_{t-1} D_{H \downarrow-1}+\varepsilon_{t}$, adjusted for heteroscedasticity and autocomelation using the Newey-West estimator; the truncation lag, which is based on the number of observations, is 4 . T-statistics for $\beta_{a}$ through $\beta_{5}$ are shown in parentheses below their coefficient values. $F_{D F}$ is the $F$-statistic for the test $\beta_{1}=\beta_{2}=\beta_{4}=\beta_{s}=0$ (the standard ADF test for a unit root, adjusted for heteroscedasticity); $F_{n}$ is the $F$-statistic for the test $\beta_{4}=\beta_{5}=0$ (no effective intervention); the value in parentheses below each $F_{D F}$-value is the t-statistic on $e_{t-1}$ when the $F_{D F}$ test restrictions are imposed (the standard unit root specification); the value below each $F_{N V}$ is the t-statistic on $e_{t-1}$ when the $F_{N V}$ test restrictions are imposed (constant autoregressive coefficient but regime specific intercepts). $\sigma$ is the size of the non-intervention band, based on minimum $A I C$. The 5 percent critical value used for $\beta_{3}$ is 2.87 ; for the other parameters it is 2.0 . 
Table 3. Estimates Based on Minimum AIC, 1981:03-2001:05

\begin{tabular}{|c|c|c|c|c|c|c|c|c|c|}
\hline & $\sigma$ & $\beta_{0}$ & $\beta_{1}$ & $\beta_{2}$ & $\beta_{3}$ & $\beta_{4}$ & $\beta_{5}$ & $F_{D F}$ & $F_{I N}$ \\
\hline \multicolumn{10}{|c|}{ Advanced Economies - G7 } \\
\hline United States & $\begin{array}{l}0.50 \\
5\end{array}$ & $\begin{array}{c}0.381 \\
(3.12)\end{array}$ & $\begin{array}{r}-0.026 \\
(4.93)\end{array}$ & $\begin{array}{c}0.021 \\
(4.84)\end{array}$ & $\begin{array}{r}-0.081 \\
(3.12)\end{array}$ & $\begin{array}{r}0.003 \\
(2.86)\end{array}$ & $\begin{array}{r}-0.002 \\
(1.80)\end{array}$ & $\begin{array}{c}9.68 \\
(1.10)\end{array}$ & $\begin{array}{c}4.25 \\
(4.55)\end{array}$ \\
\hline United Kingdom & $\begin{array}{l}0.75 \\
5\end{array}$ & $\begin{array}{r}0.684 \\
(4.21)\end{array}$ & $\begin{array}{r}-0.042 \\
(6.05)\end{array}$ & $\begin{array}{c}0.026 \\
(6.78)\end{array}$ & $\begin{array}{r}-0.149 \\
(4.21)\end{array}$ & $\begin{array}{r}0.006 \\
(3.64)\end{array}$ & $\begin{array}{r}-0.002 \\
(2.17)\end{array}$ & $\begin{array}{l}22.11 \\
(2.18)\end{array}$ & $\begin{array}{l}10.26 \\
(6.76)\end{array}$ \\
\hline Germany & $\begin{array}{l}0.50 \\
1\end{array}$ & $\begin{array}{r}0.548 \\
(3.94)\end{array}$ & $\begin{array}{r}-0.015 \\
(7.42)\end{array}$ & $\begin{array}{r}0.014 \\
(7.40)\end{array}$ & $\begin{array}{r}-0.119 \\
(3.94)\end{array}$ & $\begin{array}{r}0.002 \\
(4.35)\end{array}$ & $\begin{array}{r}-0.001 \\
(3.36)\end{array}$ & $\begin{array}{l}19.44 \\
(1.85)\end{array}$ & $\begin{array}{c}9.63 \\
(7.13)\end{array}$ \\
\hline Japan & $\begin{array}{l}0.25 \\
1\end{array}$ & $\begin{array}{r}0.239 \\
(2.09)\end{array}$ & $\begin{array}{r}-0.058 \\
(7.00)\end{array}$ & $\begin{array}{r}0.034 \\
(6.97)\end{array}$ & $\begin{array}{r}-0.051 \\
(2.08)\end{array}$ & $\begin{array}{r}0.010 \\
(5.55)\end{array}$ & $\begin{array}{r}-0.006 \\
(5.45)\end{array}$ & $\begin{array}{l}15.41 \\
(1.61)\end{array}$ & $\begin{array}{l}17.75 \\
(4.31)\end{array}$ \\
\hline France & $\begin{array}{c}0.50 \\
10^{-1}\end{array}$ & $\begin{array}{l}0.567 \\
(4.00)\end{array}$ & $\begin{array}{r}-0.011 \\
(7.91)\end{array}$ & $\begin{array}{c}0.012 \\
(6.05)\end{array}$ & $\begin{array}{r}-0.123 \\
(4.00)\end{array}$ & $\begin{array}{c}0.001 \\
(3.18)\end{array}$ & $\begin{array}{r}-0.002 \\
(4.33)\end{array}$ & $\begin{array}{l}22.55 \\
(2.01)\end{array}$ & $\begin{array}{l}12.66 \\
(6.84)\end{array}$ \\
\hline Canada & $\begin{array}{l}0.50 \\
1\end{array}$ & $\begin{array}{c}0.612 \\
(4.69)\end{array}$ & $\begin{array}{r}-0.043 \\
(17.76)\end{array}$ & $\begin{array}{r}0.022 \\
(5.01)\end{array}$ & $\begin{array}{r}-0.129 \\
(4.69)\end{array}$ & $\begin{array}{r}0.005 \\
(8.58)\end{array}$ & $\begin{array}{r}-0.002 \\
(1.57)\end{array}$ & $\begin{array}{l}11.18 \\
(0.80)\end{array}$ & $\begin{array}{c}3.12 \\
(5.73)\end{array}$ \\
\hline Italy & $\begin{array}{l}0.75 \\
3\end{array}$ & $\begin{array}{c}0.464 \\
(2.69)\end{array}$ & $\begin{array}{r}-0.016 \\
(5.03)\end{array}$ & $\begin{array}{r}0.025 \\
(4.06)\end{array}$ & $\begin{array}{r}-0.098 \\
(2.69)\end{array}$ & $\begin{array}{c}0.002 \\
(2.85)\end{array}$ & $\begin{array}{r}-0.002 \\
(1.78)\end{array}$ & $\begin{array}{c}9.47 \\
(1.56)\end{array}$ & $\begin{array}{c}4.36 \\
(4.25)\end{array}$ \\
\hline \multicolumn{10}{|c|}{ Other Advanced Economies } \\
\hline Australia & $\begin{array}{l}0.25 \\
2\end{array}$ & $\begin{array}{c}0.372 \\
(3.30)\end{array}$ & $\begin{array}{r}-0.025 \\
(6.11)\end{array}$ & $\begin{array}{r}0.042 \\
(8.97)\end{array}$ & $\begin{array}{r}-0.080 \\
(3.33)\end{array}$ & $\begin{array}{r}0.004 \\
(4.57)\end{array}$ & $\begin{array}{r}-0.006 \\
(5.40)\end{array}$ & $\begin{array}{l}15.84 \\
(1.60)\end{array}$ & $\begin{array}{l}12.51 \\
(5.82)\end{array}$ \\
\hline New Zealand & $\begin{array}{c}0.50 \\
12\end{array}$ & $\begin{array}{c}0.749 \\
(5.11)\end{array}$ & $\begin{array}{r}-0.035 \\
(4.97)\end{array}$ & $\begin{array}{c}0.029 \\
(7.25)\end{array}$ & $\begin{array}{r}-0.165 \\
(5.10)\end{array}$ & $\begin{array}{r}0.003 \\
(2.43)\end{array}$ & $\begin{array}{r}-0.003 \\
(2.88)\end{array}$ & $\begin{array}{l}18.48 \\
(1.31)\end{array}$ & $\begin{array}{c}5.17 \\
(6.70)\end{array}$ \\
\hline Spain & $\begin{array}{l}0.75 \\
1\end{array}$ & $\begin{array}{r}0.269 \\
(2.92)\end{array}$ & $\begin{array}{r}-0.041 \\
(1.74)\end{array}$ & $\begin{array}{c}0.034 \\
(5.05)\end{array}$ & $\begin{array}{r}-0.059 \\
(2.92)\end{array}$ & $\begin{array}{r}0.008 \\
(1.47)\end{array}$ & $\begin{array}{r}-0.005 \\
(3.78)\end{array}$ & $\begin{array}{l}18.84 \\
(1.45)\end{array}$ & $\begin{array}{c}21.64 \\
(3.42)\end{array}$ \\
\hline Belgium & $\begin{array}{l}0.25 \\
1\end{array}$ & $\begin{array}{r}0.359 \\
(3.32)\end{array}$ & $\begin{array}{r}-0.013 \\
(4.78)\end{array}$ & $\begin{array}{r}0.010 \\
(3.66)\end{array}$ & $\begin{array}{r}-0.078 \\
(3.32)\end{array}$ & $\begin{array}{r}0.002 \\
(3.37)\end{array}$ & $\begin{array}{r}-0.002 \\
(2.49)\end{array}$ & $\begin{array}{l}14.08 \\
(2.23)\end{array}$ & $\begin{array}{l}13.10 \\
(5.43)\end{array}$ \\
\hline Israel & $\begin{array}{l}0.25 \\
2\end{array}$ & $\begin{array}{r}0.659 \\
(4.47)\end{array}$ & $\begin{array}{r}-0.025 \\
(6.17)\end{array}$ & $\begin{array}{r}0.032 \\
(9.02)\end{array}$ & $\begin{array}{r}-0.143 \\
(4.47)\end{array}$ & $\begin{array}{r}0.004 \\
(4.39)\end{array}$ & $\begin{array}{r}-0.004 \\
(5.00)\end{array}$ & $\begin{array}{l}36.28 \\
(2.35)\end{array}$ & $\begin{array}{l}22.80 \\
(7.55)\end{array}$ \\
\hline \multicolumn{10}{|c|}{ Emerging Countries } \\
\hline India & $\begin{array}{c}0.5 \\
1\end{array}$ & $\begin{array}{r}0.105 \\
(1.62)\end{array}$ & $\begin{array}{r}-0.175 \\
(24.22)\end{array}$ & $\begin{array}{c}0.020 \\
(3.06)\end{array}$ & $\begin{array}{r}-0.024 \\
(1.74)\end{array}$ & $\begin{array}{r}0.040 \\
(22.04)\end{array}$ & $\begin{array}{r}-0.001 \\
(0.68)\end{array}$ & $\begin{array}{l}28.29 \\
(1.54)\end{array}$ & $\begin{array}{l}48.89 \\
(1.68)\end{array}$ \\
\hline Indonesia & $\begin{array}{c}1 \\
11\end{array}$ & $\begin{array}{c}0.547 \\
(2.91)\end{array}$ & $\begin{array}{r}-0.189 \\
(3.49)\end{array}$ & $\begin{array}{l}0.145 \\
(2.77)\end{array}$ & $\begin{array}{r}-0.118 \\
(2.91)\end{array}$ & $\begin{array}{r}0.027 \\
(1.85)\end{array}$ & $\begin{array}{r}-0.008 \\
(0.71)\end{array}$ & $\begin{array}{r}14.05 \\
(0.41)\end{array}$ & $\begin{array}{c}5.41 \\
(4.15)\end{array}$ \\
\hline Korea & $\begin{array}{c}0.75 \\
2\end{array}$ & $\begin{array}{l}0.481 \\
(3.92)\end{array}$ & $\begin{array}{r}-0.070 \\
(2.21)\end{array}$ & $\begin{array}{r}0.015 \\
(4.40)\end{array}$ & $\begin{array}{r}-0.106 \\
(3.93)\end{array}$ & $\begin{array}{r}0.012 \\
(1.70)\end{array}$ & $\begin{array}{r}-0.001 \\
(0.95)\end{array}$ & $\begin{array}{c}12.84 \\
(2.20)\end{array}$ & $\begin{array}{l}13.49 \\
(5.19)\end{array}$ \\
\hline Malaysia & $\begin{array}{c}1.0 \\
8\end{array}$ & $\begin{array}{l}0.202 \\
(2.58)\end{array}$ & $\begin{array}{r}-0.024 \\
(2.67)\end{array}$ & $\begin{array}{r}0.017 \\
(2.21)\end{array}$ & $\begin{array}{r}-0.044 \\
(2.59)\end{array}$ & $\begin{array}{c}0.004 \\
(1.61)\end{array}$ & $\begin{array}{r}0.000 \\
(0.31)\end{array}$ & $\begin{array}{c}2.09 \\
(1.20)\end{array}$ & $\begin{array}{c}0.80 \\
(3.08)\end{array}$ \\
\hline Philippines & $\begin{array}{c}0.25 \\
4\end{array}$ & $\begin{array}{r}0.336 \\
(2.90)\end{array}$ & $\begin{array}{r}-0.046 \\
(4.57)\end{array}$ & $\begin{array}{r}0.097 \\
(4.57)\end{array}$ & $\begin{array}{r}-0.071 \\
(2.92)\end{array}$ & $\begin{array}{r}0.009 \\
(4.07)\end{array}$ & $\begin{array}{r}-0.017 \\
(3.87)\end{array}$ & $\begin{array}{l}36.85 \\
(2.35)\end{array}$ & $\begin{array}{l}46.50 \\
(3.84)\end{array}$ \\
\hline Thailand & $\begin{array}{c}0.75 \\
7\end{array}$ & $\begin{array}{r}0.662 \\
(2.97)\end{array}$ & $\begin{array}{r}-0.080 \\
(3.53)\end{array}$ & $\begin{array}{r}0.039 \\
(8.89)\end{array}$ & $\begin{array}{r}-0.143 \\
(2.97)\end{array}$ & $\begin{array}{l}0.012 \\
(2.06)\end{array}$ & $\begin{array}{r}0.000 \\
(0.23)\end{array}$ & $\begin{array}{c}4.86 \\
(0.81)\end{array}$ & $\begin{array}{c}1.15 \\
(3.50)\end{array}$ \\
\hline South Africa & $\begin{array}{c}1.0 \\
9 \\
\end{array}$ & $\begin{array}{r}0.467 \\
(3.34)\end{array}$ & $\begin{array}{r}-0.070 \\
(4.65)\end{array}$ & $\begin{array}{c}0.004 \\
(0.19)\end{array}$ & $\begin{array}{r}-0.102 \\
(3.35)\end{array}$ & $\begin{array}{r}0.010 \\
(2.94)\end{array}$ & $\begin{array}{r}0.006 \\
(1.20)\end{array}$ & $\begin{array}{r}14.50 \\
(0.62)\end{array}$ & $\begin{array}{l}11.74 \\
(4.86)\end{array}$ \\
\hline
\end{tabular}


Table 3 (concluded). Estimates Based on Minimum AIC, 1981:03-2001:05

\begin{tabular}{lccccccccc}
\hline & $\sigma$ & $\beta_{0}$ & $\beta_{1}$ & $\beta_{2}$ & $\beta_{3}$ & $\beta_{4}$ & $\beta_{5}$ & $F_{D F}$ & $F_{D N}$ \\
\hline \multirow{7}{*}{ Argentina } & 0.50 & 1.077 & -0.156 & 0.134 & -0.218 & 0.011 & -0.017 & 15.52 & 5.88 \\
& 1 & $(2.67)$ & $(5.19)$ & $(3.92)$ & $(2.66)$ & $(1.31)$ & $(2.41)$ & $(1.24)$ & $(3.53)$ \\
Brazil & 0.25 & 0.748 & -0.108 & 0.085 & -0.173 & 0.018 & -0.011 & 40.03 & 24.71 \\
& 10 & $(4.16)$ & $(5.33)$ & $(5.36)$ & $(4.18)$ & $(3.88)$ & $(3.07)$ & $(2.13)$ & $(6.05)$ \\
Chile & 0.50 & 0.167 & -0.029 & 0.244 & -0.034 & 0.005 & -0.043 & 27.99 & 41.37 \\
& 9 & $(1.42)$ & $(3.18)$ & $(16.43)$ & $(1.42)$ & $(2.50)$ & $(16.32)$ & $(1.69)$ & $(2.54)$ \\
Colombia & 0.50 & 0.119 & -0.031 & 0.032 & -0.024 & 0.006 & -0.004 & 8.04 & 10.25 \\
& 1 & $(1.31)$ & $(7.58)$ & $(2.58)$ & $(1.32)$ & $(6.75)$ & $(1.78)$ & $(1.71)$ & $(3.11)$ \\
Costa Rica & 0.25 & 0.910 & -0.027 & 0.020 & -0.196 & 0.003 & -0.001 & 17.86 & 5.47 \\
& 10 & $(8.52)$ & $(5.53)$ & $(4.62)$ & $(8.52)$ & $(2.94)$ & $(1.01)$ & $(4.98)$ & $(10.66)$ \\
Mexico & 1.0 & 0.368 & -0.136 & 0.057 & -0.079 & 0.026 & -0.012 & 21.18 & 27.70 \\
& 11 & $(3.83)$ & $(4.11)$ & $(3.60)$ & $(3.81)$ & $(3.69)$ & $(3.73)$ & $(3.96)$ & $(4.50)$ \\
Paraguay & 0.25 & 0.467 & -0.096 & 0.129 & -0.099 & 0.021 & -0.016 & 35.75 & 44.68 \\
& 7 & $(3.43)$ & $(4.77)$ & $(4.72)$ & $(3.45)$ & $(3.87)$ & $(2.65)$ & $(1.77)$ & $(3.39)$ \\
Uruguay & 0.75 & 0.548 & -0.082 & 0.260 & -0.109 & 0.009 & -0.046 & 56.27 & 56.73 \\
& 1 & $(2.41)$ & $(3.58)$ & $(1.54)$ & $(2.40)$ & $(3.29)$ & $(1.42)$ & $(1.12)$ & $(1.97)$ \\
\hline
\end{tabular}

Note: The results for this table are from least squares estimates of equation (2),

$$
\Delta e_{t}=\beta_{0}+\beta_{1} D_{L}+\beta_{2} D_{H}+\beta_{3} e_{t-1}+\beta_{4} e_{t-1} D_{t, t-1}+\beta_{5} e_{t-1} D_{H, t-1}+\sum_{j=1}^{p}\left(\gamma_{j}+\varphi_{j} D_{t, t-j}+\pi_{j} D_{H, t-j}\right) \Delta e_{t-j}+e_{t}
$$

adjusted for heteroscedasticity using the White estimator. The number of lags used to correct for autocorrelation is based on the minimum $A I C$. The model is estimated with lagged dependent variables up to 13 lags for each $\sigma$ and the minimum $A I C$ noted. The model reported in the table is that which has the minimum of the minimum AICs (minimum across all $\sigma$ ). T-statistics for $\beta_{0}$ through $\beta_{5}$ are shown in parentheses below their coefficicnt values. $F_{D F}$ is the $F$-statistic for the test $\beta_{1}=\beta_{2}=\beta_{4}=\beta_{5}=0$ (the standard ADF test for a unit root, adjusted for heteroscedasticity); $F_{L N}$ is the $F$-statistic for the test $\beta_{4}=\beta_{5}=0$ (no effective intervention); the value in parentheses below each $F_{D F}$-value is the t-statistic on $e_{t-1}$ when the $F_{D F}$ test restrictions are imposed (the standard unit root specification); the value below each $F_{N N}$-value is the t-statistic on $e_{t-1}$ when the $F_{E V}$ test restrictions are imposed (constant autoregressive coefficient but regime-specific intercepts). $\sigma$ is the size of the non-intervention band, based on minimum $A I C$. The 5 percent critical value for $\beta_{3}$ is 2.87 ; for the other parameters it is 2.0 . 
Figure 1. Real Effective Exchange Rates

United States

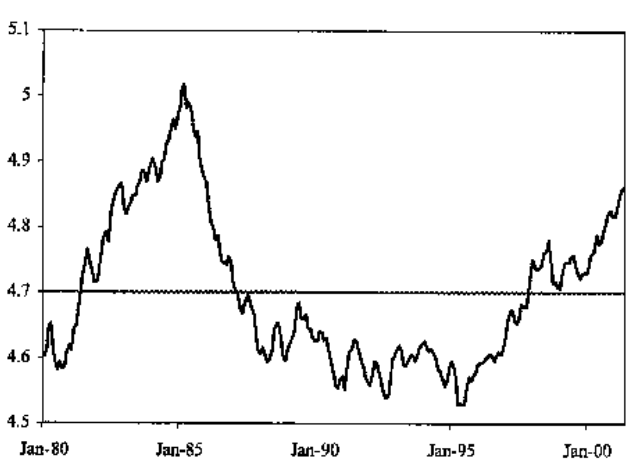

Germany

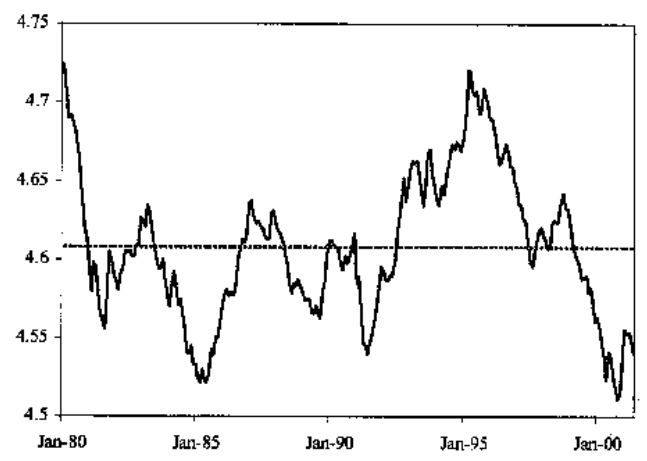

Canada

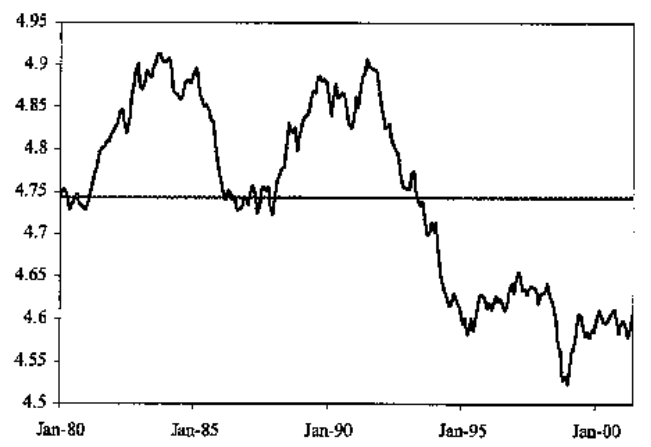

United Kingdom

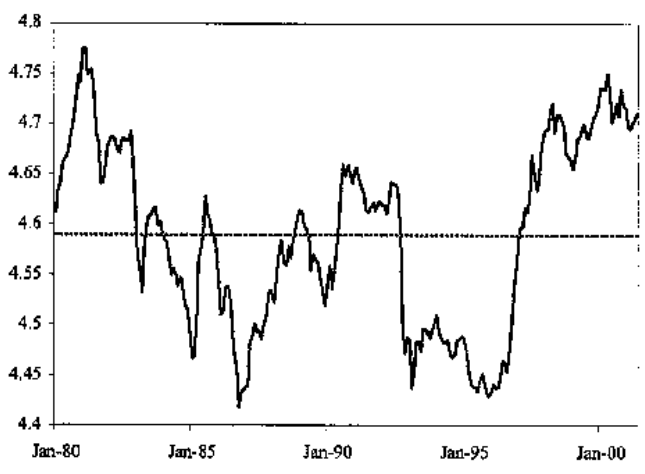

Japan

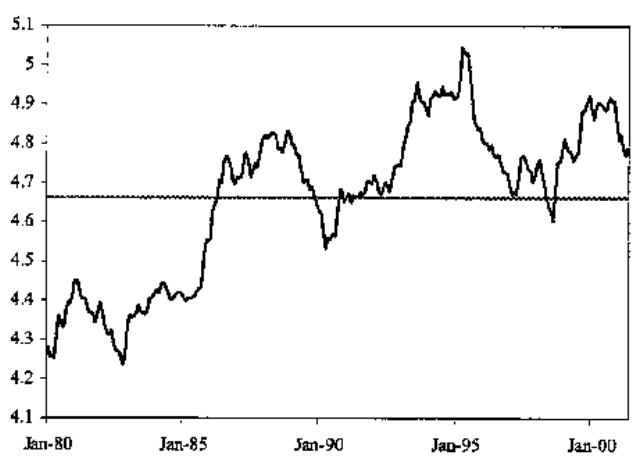

France

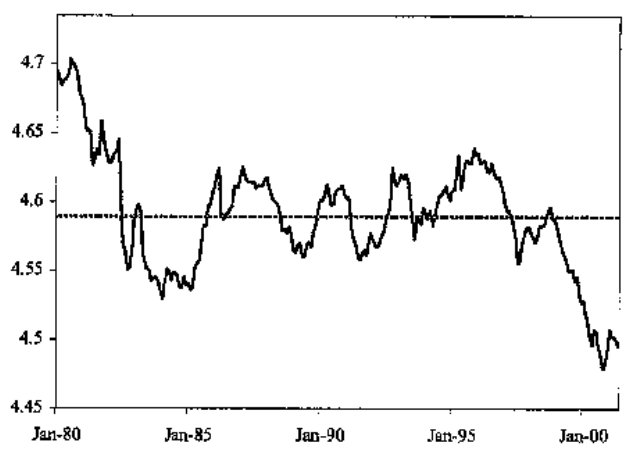


Figure 1 (continued). Real Effective Exchange Rates

Italy

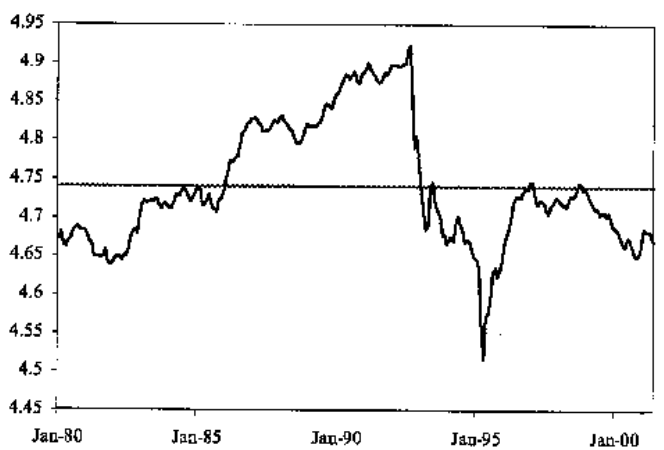

Belgium

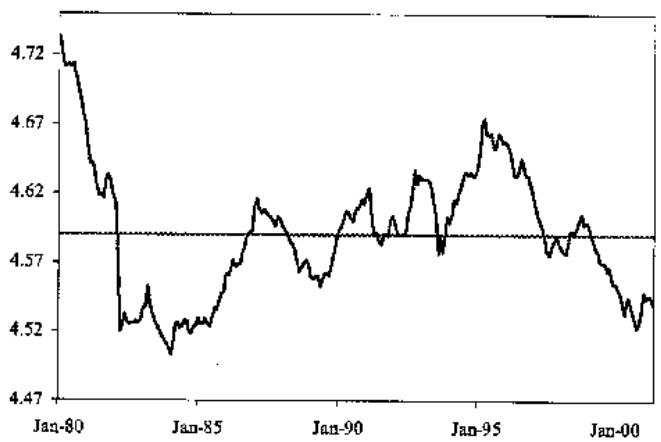

New Zealand

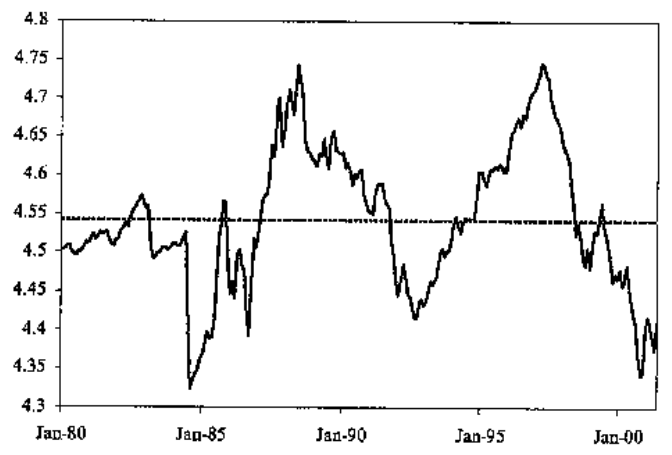

Australia

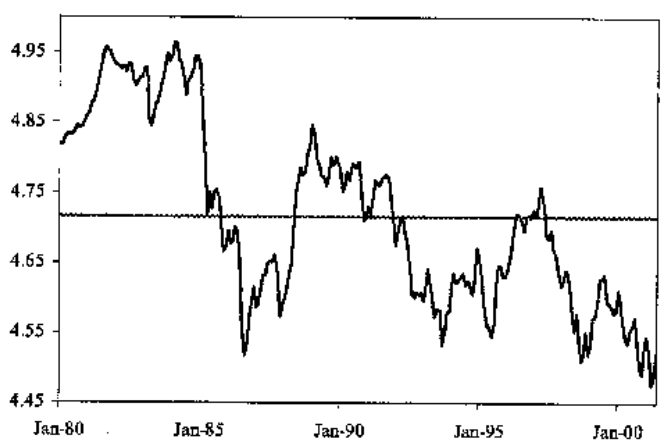

Israel

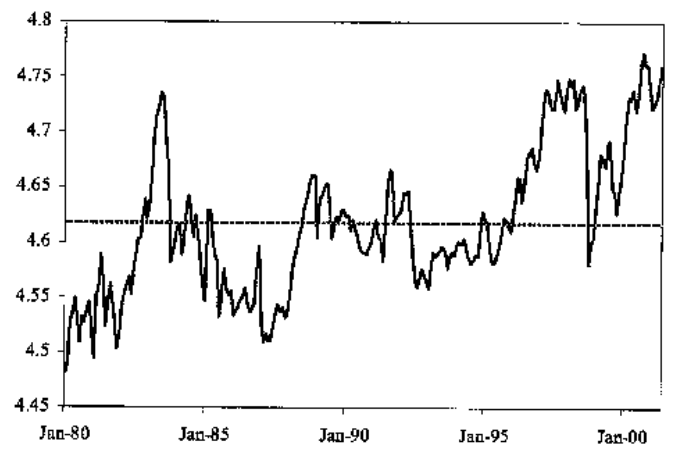

Spain

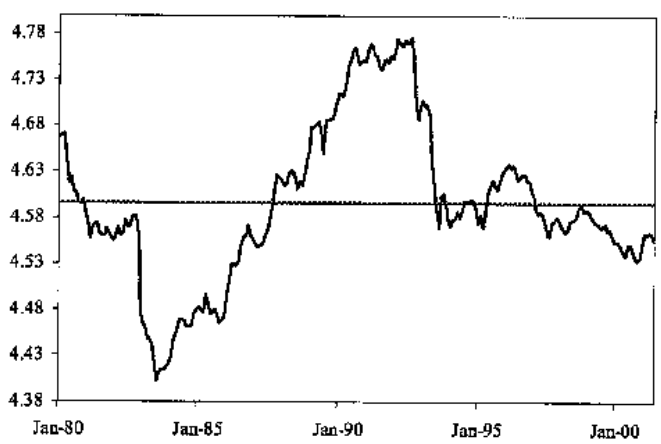


Figure 1 (continued). Real Effective Exchange Rates

India

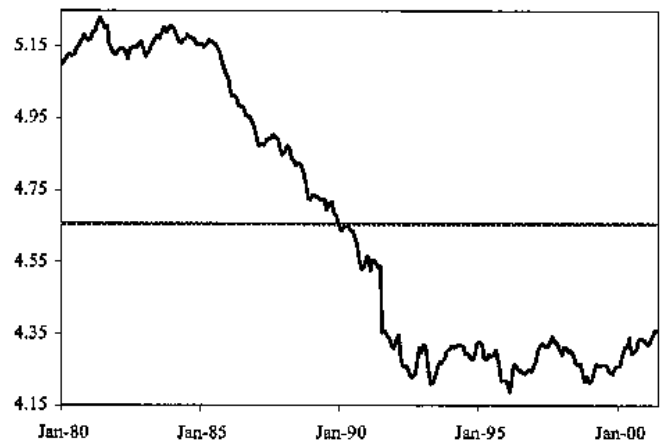

Korea

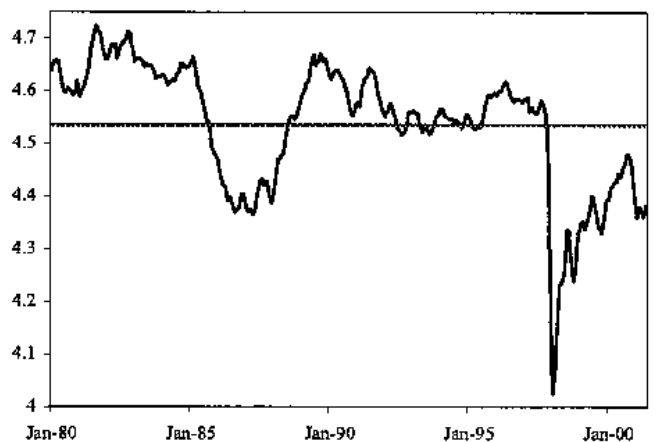

Philippines

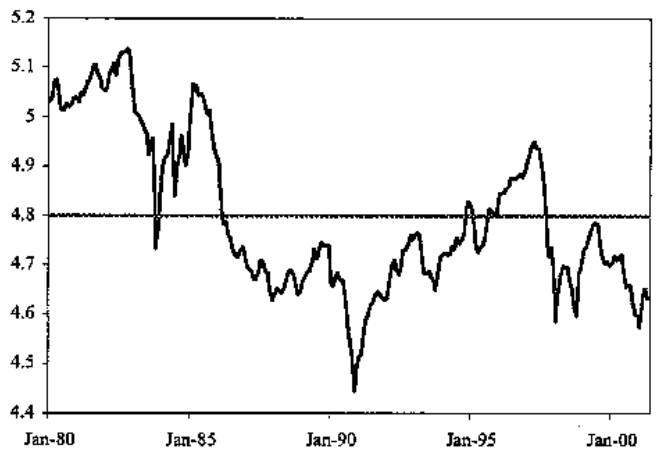

Indonesia

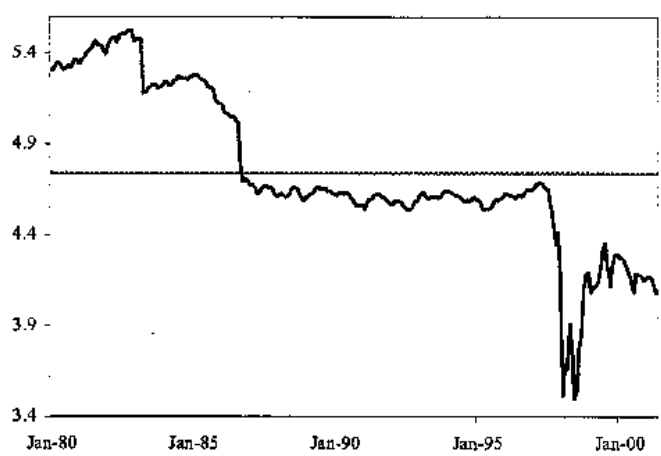

Malaysia

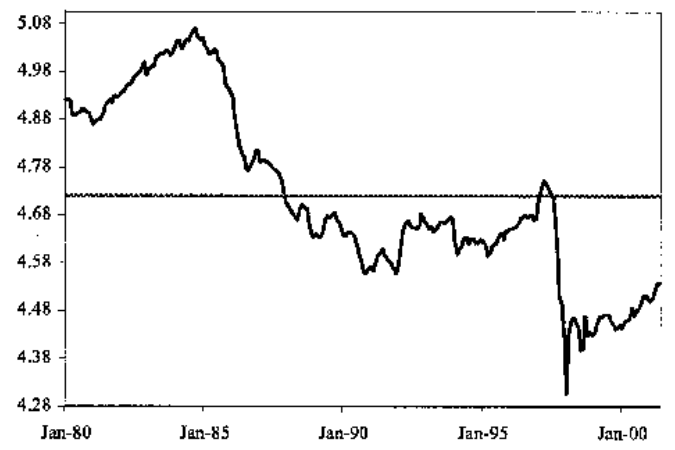

Thailand

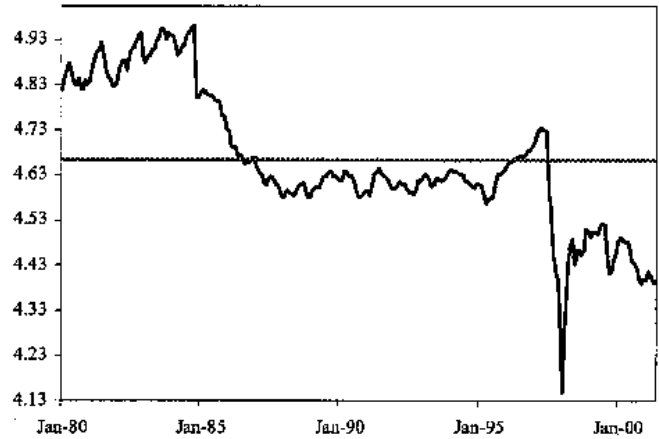


Figure 1 (continued). Real Effective Exchange Rates

South Africa

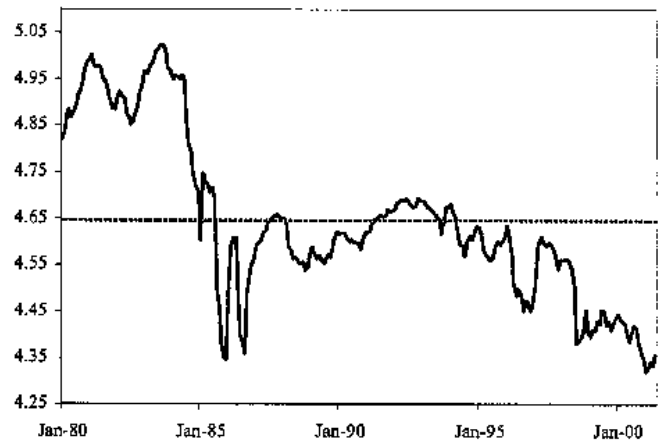

Brazil

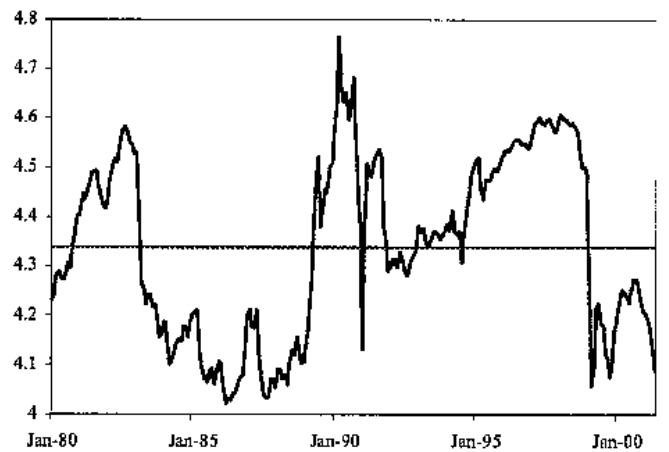

Colombia

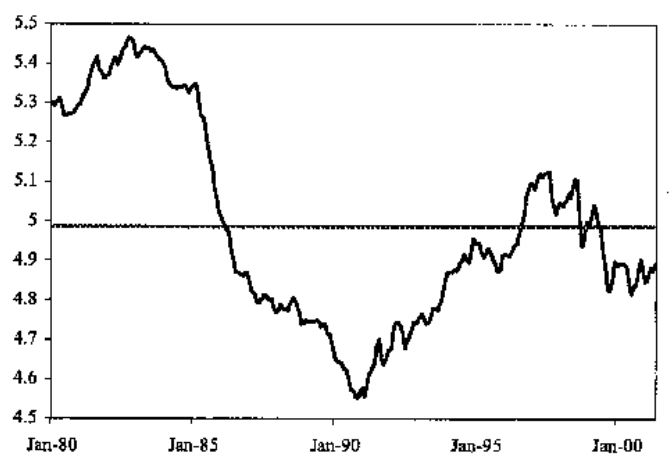

Argentina

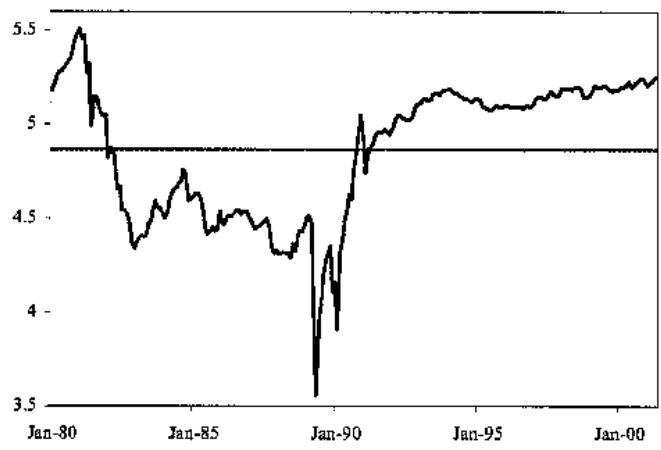

Chile

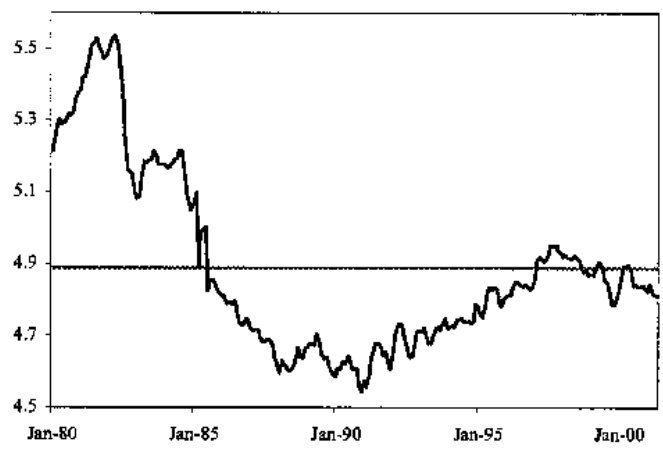

Costa Rica

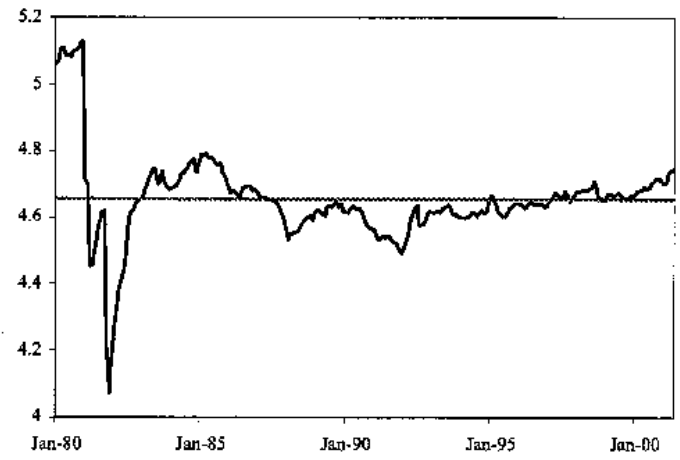


Figure 1 (concluded). Real Effective Exchange Rates

Mexico

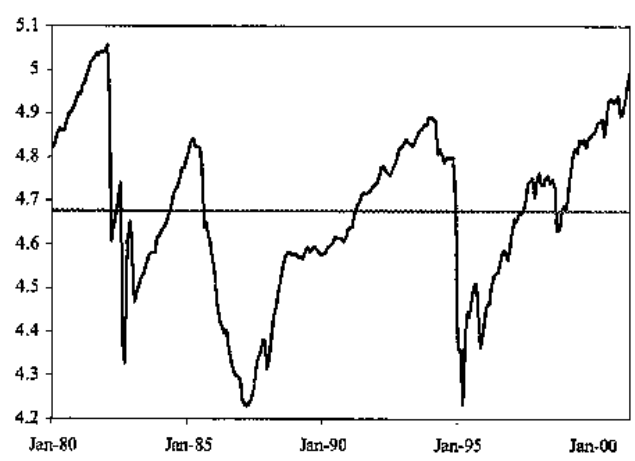

Uruguay

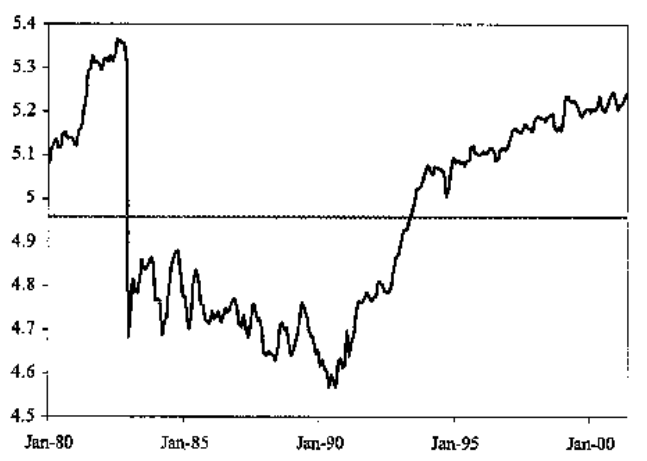

Paraguay

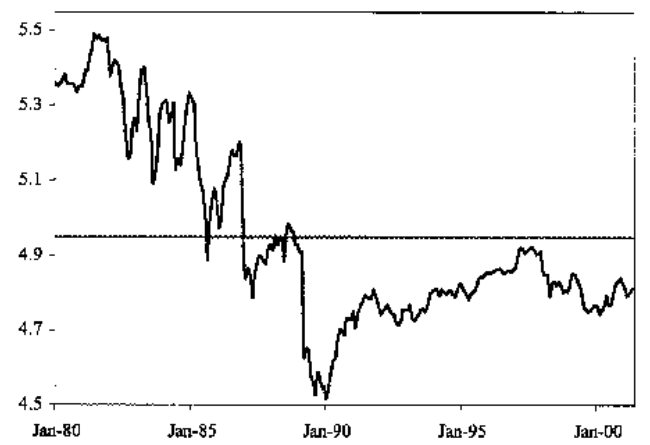




\section{Derivation of Proposition 1}

The solutions reported in Proposition 1 can be derived by solving for equilibrium conditions in each of three zones. Let $(\mathbf{H}),(\mathbf{0}),(\mathbf{L})$ correspond to the intervals $\left(-\infty, e_{L}\right),\left[e_{H}, e_{L}\right]$, and $\left(e_{H}, \infty\right)$. Suppose first that $\bar{e}_{t+1}$ is in (0). The government chooses $s_{t}=0$, and $E_{t} e_{t+1}=\bar{e}_{t+1}$. From (I),

$$
\bar{e}_{t+1}=e_{t}-z_{t} \Rightarrow \rho e_{t}+\beta z_{t}=e_{t}-z_{t}
$$

and this solves as $z_{t}=\left(1-\theta_{0}\right) e_{t}$. From interest parity,

$$
\bar{e}_{t+1}=e_{t}-z_{t}=\theta_{0} e_{t}
$$

This is (E.2), and defines the region (O) as stated. If $\bar{e}_{t+1}$ is in (L), we have

$$
E_{t} e_{t+1}=\lambda_{L} e_{L}+\left(1-\lambda_{L}\right) \bar{e}_{t+1}
$$

Interest parity implies

$$
\lambda_{L} e_{L}+\left(1-\lambda_{L}\right)\left(\rho e_{t}+\beta z_{t}\right)=e_{t}-z_{t}
$$

This solves as $z_{t}=-\mu_{L}+\left(1-\theta_{L}\right) e_{t}$ and

$$
E_{t} e_{t+1}=e_{t}-z_{t}=\mu_{L}+\theta_{L} e_{t}
$$

We have (E.1). A similar argument derives (E.3) when $\vec{e}_{t+1}$ lies in (H). 


\section{REFERENCES}

Andrés, J., I. Hernando, and M. Krüger, 1996, "Growth Inflation and the Exchange Rate Regime," Economics Letters, Vol. 53 (1), pp. 61-65.

Baillie, R.T., and W.P. Osterberg, 2000, "Deviations From Daily Uncovered Interest Rate Parity and the Role of Intervention," Journal of International Financial Markets, Institutions and Money, Vol. 10, pp. 363-79.

Bergman, U.M., and J. Hansson, 2000, "Real Exchange Rates and Switching Regimes," mimeo, Department of Economics, Lund University, Sweden.

Calvo, G.A., and C.M. Reinhart, 2000, "Fear of Floating," NBER Working Paper No. 7993, (Cambridge, Massachusetts: MIT Press).

____ 2001, "Fixing for Your Life," NBER Working Paper No. 8006, (Cambridge, Massachusetts: MIT Press).

- and C.A. Végh, 2000, "Targeting the Real Exchange Rate: Theory and Evidence," Journal of Development Economics, Vol. 47 (1), pp. 97-133.

Campa, J.M., and L.S. Goldberg, 1999, "Investment, Pass-through, and Exchange Rates: A Cross-Country Analysis," International Economic Review, Vol. 40 (2), pp. 287-314.

Cashin, P., and C.J. McDermott, 2001, "An Unbiased Appraisal of Purchasing Power Parity," IMF Working Paper 01/196 (Washington: International Monetary Fund).

Chung, Y.-W., and K.S. Lai, 1998, "Parity Reversion in Real Exchange Rates During the Post-Bretton Woods Period," Journal of International Money and Finance, Vol. 17, pp. 597-614.

DeGrauwe, P., and I. Vansteenkiste, 2001, "Exchange Rates and Fundamentals: A NonLinear Relationship?" CESifo Working Paper No. 577 (Munich, Germany: Center for Economic Studies \& Ifo Institute for Economic Research).

Domaç, I., and G. Shabsigh, 1999, "Real Exchange Rate Behavior and Economic Growth: Evidence from Egypt, Jordan, Morocco, and Tunisia," IMF Working Paper 99/40 (Washington: International Monetary Fund).

Edwards, S., and M.A. Savastano, 1999, "Exchange Rates in Emerging Economies: What Do We Know? What Do We Need to Know?" NBER Working Paper No. 7228. (Cambridge, Massachusetts: MIT Press).

Eichenbaum, M., and C. Evans, 1995, "Some Empirical Evidence on Shocks to Monetary Policy on Exchange Rates," Quarterly Journal of Economics, Vol. 110 (November), pp. 975-1010. 
Engel, C., 2000, “Long-run PPP May Not Hold After All," Journal of International Economics, Vol. 57, pp. 243-273.

Frankel, J.A., and A.K. Rose, 1996, "A Panel Project on Purchasing Power Parity: Mean Reversion Within and Between Countries," Journal of International Economics, Vol. 40, pp. 209-224.

Froot, K.A., and K. Rogoff, 1995, "Perspectives on PPP and Long-Run Real Exchange Rates," in Handbook of International Economics, ed. by K. Rogoff and G. Grossman (Amsterdam: North Holland).

Goldfajn, I., and R.O. Valdés, 1996, "The Aftermath of Appreciations," NBER Working Paper No. 5650 (Cambridge, Massachusetts: MIT Press).

Granger, C., and T. Teräsvirta, 1993, Modelling Nonlinear Economic Relationships (Oxford: Oxford University Press).

Hamilton, H., 1989, "A New Approach to the Economic Analysis of Nonstationary Time Series Subject To Changes in Regime," Econometrica, Vol. 57, pp. 357-84.

Kamin, S.B., and J.H. Rogers, 2000, "Output and the Real Exchange Rate in Developing Countries: An Application to Mexico," Journal of Development Economics, Vol. 61 (February), pp. 85-109.

Kilian, L., and M.P. Taylor, 2001, "Why Is It so Difficult to Beat the Random Walk Forecast of Exchange Rates," mimeo, University of Michigan and University of Warwick.

Lafrance, R., P. Osakwe, and P. St. Amant, 1998, "Evaluating Alternative Measures of the Real Effective Exchange Rate," Bank of Canada Working Paper No.98-20 (Ottawa, Canada: Bank of Canada).

Levy-Yeyati, E., and F. Sturzenegger, 2001, "To Float or To Trail? Evidence on the Impact of Exchange Rate Regimes," draft, Business School, Universidad Torcuato di Tella.

Lothian, J., and M.P. Taylor, 1997, "Real Exchange Rate Behavior: The Recent Float from the Perspective of the Past Two Centuries," Journal of Political Economy, Vol. 104, pp. 488-509.

Lütkepohl, H., 1993, Introduction to Multiple Time Series Analysis (Heidelberg: SpringerVerlag, $2^{\text {nd }}$ ed.).

MacKinnon, J.G., 1991, "Critical Values for Cointegration Tests," in Long-Run Economic Relationships: Readings in Cointegration, ed. by R.F. Engle and C.W. Granger (Oxford: Oxford University Press). 
McCallum, B., 1994, "A Reconsideration of the Uncovered Interest Parity Relationship," Journal of Monetary Economics, Vol. 33, pp. 105-132.

Meese, R.A., and K. Rogoff, 1988, "Was It Real? The Exchange Rate-Interest Differential Relation Over the Modern Floating-Rate Period," Journal of Finance, Vol. 43, pp. 933-948.

Michael, P., R. Nobay, and D. Peel, 1997, "Transactions Costs and Nonlinear Adjustment in Real Exchange Rates: An Empirical Investigation," Journal of Political Economy, Vol. 105, pp. 862-879.

Nucci, F., and A. Pozzolo, 2001, "Investment and the Exchange Rate: An Analysis with Firm-Level Panel Data," European Economic Review, Vol. 45, pp. 259-283.

Obstfeld, M., and K. Rogoff, 2000, "The Six Major Puzzles in International Macroeconomics: Is There a Common Cause?" in NBER Macroeconomics Annual (Cambridge, Massachusetts: MIT Press).

O'Connell, P.G.J., 1997, "Perspectives on Purchasing Power Parity," Ph.D thesis, Harvard University.

Papell, D.H., 1998, "Searching for Stationarity: Purchasing Power Parity Under the Current Float," Journal of International Economics, Vol. 43, pp. 312-332.

Rogoff, K., 1996, “The Purchasing Power Parity Puzzle," Journal of Economic Literature, Vol. 34 (June), pp. 647-668.

Sarno. L., and M.P. Taylor, 2002, "Purchasing Power Parity and the Real Exchange Rate," Staff Papers, International Monetary Fund, Vol. 49, No. 1, pp. 65-105.

Taylor, M.P., 1995, “The Economics of Exchange Rates," Journal of Economic Literature, Vol. 32 (March), pp. 13-47.

, D.A. Peel, and L. Sarno, 2001, "Nonlinear Mean-Reversion in Real Exchange Rates: Towards a Solution to the Purchasing Power Parity Puzzles," CEPR Discussion Paper No. 2658 (London: Centre for Economic Policy Research).

Teräsvirta, T., 1994, "Specification, Estimation, and Evaluation of Smooth Transition Autoregressive Models," Journal of the American Statistical Association, Vol. 89, pp. 208-218.

Tong, H., 1990, Nonlinear Time Series: A Dynamical System Approach (Oxford: Clarendon Press). 
Wickham, P., 2002, "Do 'Flexible' Exchange Rates of Developing Countries Behave Like the Floating Exchange Rates of Industrialized Countries?" mimeo, Research Department, (Washington: International Monetary Fund).

Yilmaz, K., 2001, "Martingale Property of Exchange Rates and Central Bank Interventions," mimeo, Koç University, Turkey.

Zanello, A., and D. Desruelle, 1997, "A Primer on the IMF's Information Notice System," IMF Working Paper 97/71 (Washington: International Monetary Fund). 